\title{
Extending periodic eddy covariance latent heat fluxes through tree sap-flow measurements to estimate long-term total evaporation in a peat swamp forest
}

\author{
A. D. Clulow ${ }^{1}$, C. S. Everson ${ }^{1}$, ${ }^{*}$ M. G. Mengistu ${ }^{1}$, J. S. Price ${ }^{2}$, A. Nickless ${ }^{3}$, and G. P. W. Jewitt ${ }^{1}$ \\ ${ }^{1}$ Centre for Water Resources Research, University of KwaZulu-Natal, Pietermaritzburg, 3209, South Africa \\ ${ }^{2}$ Department of Geography and Environmental Management, University of Waterloo, Waterloo, Ontario, N2L 3G1, Canada \\ ${ }^{3}$ Department of Statistical Sciences, University of Cape Town, Cape Town, 7701, South Africa \\ *now at: South African Environmental Observational Network-Grasslands, Forests and Wetlands Node, \\ Pietermaritzburg, 3202, South Africa
}

Correspondence to: A. D. Clulow (clulowa@ukzn.ac.za)

Received: 15 October 2014 - Published in Hydrol. Earth Syst. Sci. Discuss.: 12 December 2014

Revised: 2 May 2015 - Accepted: 5 May 2015 - Published: 28 May 2015

\begin{abstract}
A combination of measurement and modelling was used to find a pragmatic solution to estimate the annual total evaporation from the rare and indigenous Nkazana Peat Swamp Forest (PSF) on the east coast of Southern Africa to improve the water balance estimates within the area. Actual total evaporation $\left(\mathrm{ET}_{\mathrm{a}}\right)$ was measured during three window periods (between 7 and 9 days each) using an eddy covariance (EC) system on a telescopic mast above the forest canopy. Sap flows of an understory tree and an emergent tree were measured using a low-maintenance heat pulse velocity system for an entire hydrological year (October 2009 to September 2010). An empirical model was derived, describing the relationship between $\mathrm{ET}_{\mathrm{a}}$ from the Nkazana PSF and sap-flow measurements. These overlapped during two of the window periods $\left(R^{2}=0.92\right.$ and 0.90$)$, providing hourly estimates of $\mathrm{ET}_{\mathrm{a}}$ from the Nkazana PSF for a year, totalling $1125 \mathrm{~mm}$ (while rainfall was $650 \mathrm{~mm}$ ). In building the empirical model, it was found that to include the understory tree sap flow provided no benefit to the model performance. In addition, the relationship between the emergent tree sap flow with $\mathrm{ET}_{\mathrm{a}}$ between the two field campaigns was consistent and could be represented by a single empirical model $\left(R^{2}=0.90 ;\right.$ RMSE $\left.=0.08 \mathrm{~mm} \mathrm{~h}^{-1}\right)$.

During the window periods of EC measurement, no single meteorological variable was found to describe the Nkazana $\mathrm{PSF}_{\mathrm{ET}}$ a satisfactorily. However, in terms of evaporation models, the hourly FAO Penman-Monteith reference evap-
\end{abstract}

oration $\left(\mathrm{ET}_{\mathrm{o}}\right)$ best described $\mathrm{ET}_{\mathrm{a}}$ during the August 2009 $\left(R^{2}=0.75\right)$, November $2009\left(R^{2}=0.85\right)$ and March 2010 $\left(R^{2}=0.76\right)$ field campaigns, compared to the PriestleyTaylor potential evaporation $\left(\mathrm{ET}_{\mathrm{p}}\right)$ model $\left(R^{2}=0.54,0.74\right.$ and 0.62 during the respective field campaigns). From the extended record of $\mathrm{ET}_{\mathrm{a}}$ (derived in this study from sap flow) and $\mathrm{ET}_{\mathrm{o}}$, a monthly crop factor $\left(K_{\mathrm{c}}\right)$ was derived for the Nkazana PSF, providing a method of estimating longterm swamp forest water-use from meteorological data. The monthly $K_{\mathrm{c}}$ indicated two distinct periods. From February to May, it was between 1.2 and 1.4 compared with June to January, when the crop factor was 0.8 to 1.0 . The derived monthly $K_{\mathrm{c}}$ values were verified as accurate (to one significant digit) using historical data measured at the same site, also using EC, from a previous study.

The measurements provided insights into the microclimate within a subtropical peat swamp forest and the contrasting sap flow of emergent and understory trees. They showed that expensive, high-maintenance equipment can be used during manageable window periods in conjunction with low-maintenance systems, dedicated to individual trees, to derive a model to estimate long-term $\mathrm{ET}_{\mathrm{a}}$ over remote heterogeneous forests. In addition, the contrast in annual $\mathrm{ET}_{\mathrm{a}}$ and rainfall emphasised the reliance of the Nkazana PSF on groundwater. 


\section{Introduction}

Severe water scarcity in parts of South Africa has threatened the health of internationally recognised environmental areas such as the iSimangaliso Wetland Park, a UNESCO world heritage site. To optimise the management of the water balance and understand the functioning of the area, there has been a need to quantify the water-use of the dominant vegetation types of the Park such as the endangered Peat Swamp Forests (Grundling et al., 1998; Clulow et al., 2012), a dominant plant type of the Mfabeni Mire. However, little is known about the water-use characteristics of the species-diverse Peat Swamp Forests (PSFs) both locally and internationally in terms of model parametrisation. Despite significant improvements to measurement techniques over vegetated surfaces (Savage et al., 1997), these have not been of benefit for PSFs due to their remote and inaccessible nature. In addition, well-documented extreme events (such as the Demoina floods in 1987) pose a real threat in the area. Sophisticated instruments are unfortunately vulnerable to damage and malfunction in such environments and PSFs are therefore not good locations for long-term deployment of sensitive equipment, a challenge facing researchers internationally and particularly in developing countries.

There are numerous, complex evaporation sources, which interact and contribute to actual total evaporation $\left(\mathrm{ET}_{\mathrm{a}}\right)$ in the Nkazana PSF. The areas of open water fluctuate, depending on groundwater levels. Open water evaporation is well described from the early work of Penman (1948) to the more recent work of Finch (2001) and Rosenberry et al. (2007) but none accounts for the effects of dense vegetation cover on radiative shading and the prevention of convection over the water surface by a tall and dense canopy. There are surface evaporation studies of peat (Nichols and Brown, 1980; Koerselman and Beltman, 1988; Lafleur and Roulet, 1992; Thompson et al., 1999; Clulow et al., 2012), but none in the context of a subtropical swamp forest. In addition the vegetated canopy is complex. There is a dense cover of ferns, of which little is understood in terms of transpiration (Andrade and Nobel, 1997). Above the ferns, the tree canopy consists of two levels described below (understory and emergent trees) and there are tree-climbing vines. Estimating $\mathrm{ET}_{\mathrm{a}}$ of the Nkazana PSF is clearly multifaceted due to its diversity and our lack of understanding of the water-use of the specific plants, together with the potential variation in the evaporative demand within and above the canopy.

Within South Africa, the only comparable study took place over an evergreen indigenous mixed forest in the Southern Cape near the coast. Dye et al. (2008) measured $\mathrm{ET}_{\mathrm{a}}$ using eddy covariance (EC), scintillometry and Bowen ratio over 18 days in total, during three different field campaigns, representing three different seasons within the year. The periods in-between were modelled using the FAO56 PenmanMonteith reference equation of Allen et al. (1998), which generally underestimated $\mathrm{ET}_{\mathrm{a}}$ under high evaporative con- ditions and overestimated under low evaporative conditions. This was attributed to the assumption of a constant surface resistance. The Penman-Monteith equation (Monteith, 1965) was found to give the best match of modelled to observed daily $\mathrm{ET}_{\mathrm{a}}$, but required measurements or a submodel, accounting for variable canopy conductance. The more complex WAVES (CSIRO, Canberra, Australia) process-based model simulated canopy growth and water-use processes in much more detail. However, successful parametrisation of the many model inputs was a significant challenge and despite their best efforts, the WAVES output revealed an overestimation of daily $\mathrm{ET}_{\mathrm{a}}$ under conditions of low evaporative demand, which could not be corrected. They concluded that the best technique for interpolating the periods between the three field campaigns would be the Penman-Monteith equation despite the problem of the variable canopy conductance and recommended that further research into understanding the most appropriate techniques for interpolating measured data would be necessary.

Internationally, no studies were found with measurements over a comparable subtropical peat swamp forest. However, Vourlitis et al. (2002) provide a valuable study in which they attempted to measure the long-term $\mathrm{ET}_{\mathrm{a}}$ with an $\mathrm{EC}$ system over a tropical forest in Brazil. Despite the proximity to the city of Sinop (offering a nearby base from which maintenance could be conducted), power issues hampered the data collection and EC data were only collected $26 \%$ of the time. Meteorological data was therefore used to estimate the latent energy flux (LE) using the Priestley-Taylor expression.

Since the beginning of the FLUXNET project, which was established to compile long-term measurements of water vapour, carbon dioxide and energy exchanges from a global network of EC systems, the problem of complete EC data sets and gap filling of records was recognised and is still an ongoing challenge (Baldocchi et al., 1996, 2001). Falge et al. (2001) found the average data coverage for long-term EC systems to be only $65 \%$ due to system failure or data rejection with most of these located in developed countries. Clearly, despite the benefit of EC systems, long-term, continuous records of observed $\mathrm{ET}_{\mathrm{a}}$ data over indigenous subtropical and tropical forests are improbable without significant research budgets allowing daily maintenance, gap filling and the processing of data including complex spectral corrections, 3-D corrections and coordinate rotation amongst others (Massman and Lee, 2002; Finnigan et al., 2003; Hui et al., 2004). Intensive, short-term field campaigns, offering reliable, continuous records, during different seasons seem to provide an appropriate strategy to determine the annual cycle of $\mathrm{ET}_{\mathrm{a}}$. This is particularly the case in South Africa, where theft of equipment and especially batteries from the foot of visible towers is a severe limitation, although this is overcome by employing 24-h security guarding services to protect the equipment during the short-term measurement periods (Dye et al., 2008). However, this strategy only provides a 


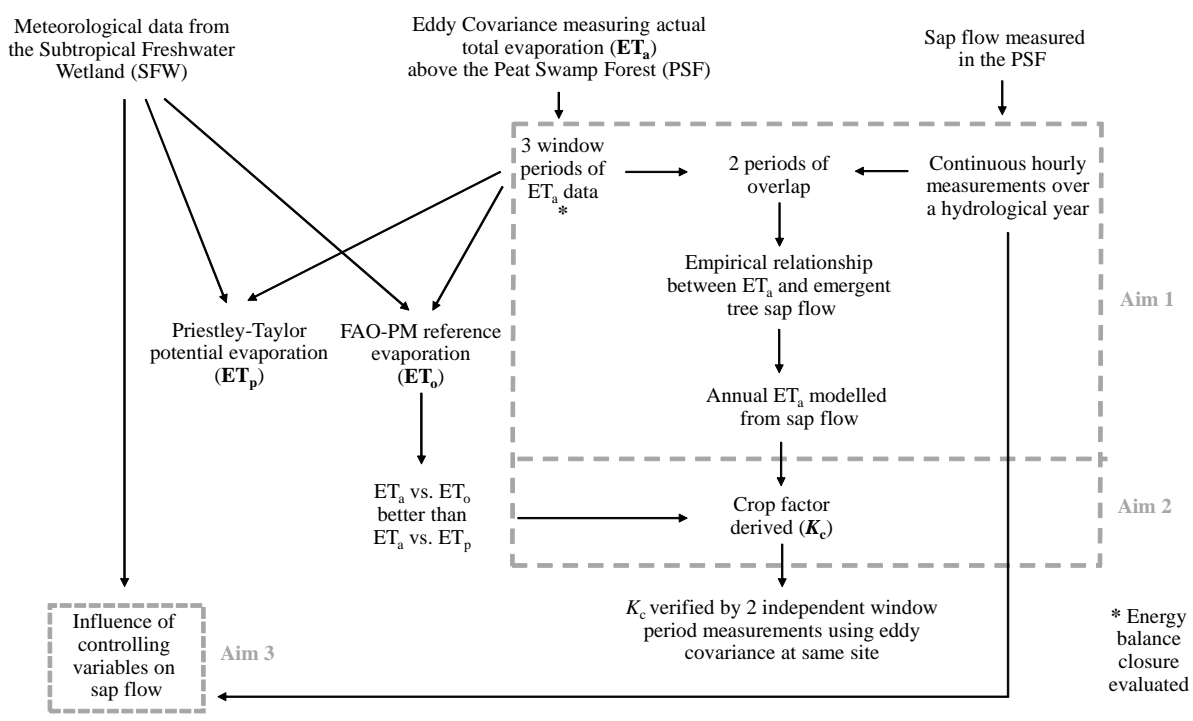

Figure 1. Flow diagram of the research strategy indicating the different measurement techniques, their combination, and link to the aims of the research.

viable solution if the $\mathrm{ET}_{\mathrm{a}}$ during the in-between periods can be adequately estimated.

Wilson et al. (2001) applied EC and sap-flow techniques in a deciduous forest of the southeastern United States, and found that there was a qualitative similarity between $\mathrm{ET}_{\mathrm{a}}$, derived using the EC technique, and tree transpiration. With the recent advances in sap-flow measurement techniques and upscaling of individual tree transpiration measurements to canopy $\mathrm{ET}_{\mathrm{a}}$, it is believed that sap-flow techniques offer a reliable, standalone, long-term solution to estimating $\mathrm{ET}_{\mathrm{a}}$ in uniform tree stands (Hatton and $\mathrm{Wu}, 1995$; Meiresonne et al., 1999; Crosbie et al., 2007). There are however, numerous complexities, bringing some doubt as to the accuracy of the absolute sap-flow results, such as the anisotropic properties of sapwood (Vandegehuchte et al., 2012), species composition effects (Wullschleger et al., 2001), tree symmetry (Vertessy et al., 1997), radial patterns of sap flow (Čermák and Nadezhdina, 1998) and changes in spatial patterns of transpiration (Traver et al., 2010). In heterogeneous and complex canopies such as the Nkazana PSF described above, sapflow systems alone are impractical for the prediction of stand $\mathrm{ET}_{\mathrm{a}}$ even with the recent advances in process-based models of vegetation function such as the Measpa model (Duursma and Medlyn, 2012). However, whether it is possible to use the qualitative relationship of sap flow with measured $\mathrm{ET}_{\mathrm{a}}$, as found by Wilson et al. (2001), remains unknown.

For these reasons, a strategy to provide a measurement and modelling framework was developed and tested, in which detailed water flux measurements were recorded using EC instruments in an indigenous, heterogeneous forest over three window periods in August 2009, November 2009 and March 2010 (Fig. 1). This minimised the cost and risk of damage to these expensive systems, and provided continuous and re- liable data from well-maintained instruments, operated by a team of scientists, but were limited to three window periods. Two of these window periods overlapped with long-term sapflow measurements, and a nearby weather station provided climatic data during the full period (Fig. 1). The sap flow and weather station systems had lower maintenance and power requirements, were less delicate, less visible, able to withstand the harsh environment, and operated for longer periods unattended (1-2 months) without compromising data quality. The aims were therefore to (1) establish whether the longterm $\mathrm{ET}_{\mathrm{a}}$ of the Nkazana PSF could be determined by this combination of EC window periods and long-term sap-flow measurements, (2) to provide a means of modelling the $\mathrm{ET}_{\mathrm{a}}$ of surrounding PSFs from nearby meteorological data and (3) to investigate the controlling climatic variables and their influence on sap flow as well as the energy fluxes and microclimate within the swamp forest (Fig. 1).

\subsection{The study area}

The study area is located in Maputaland, South Africa, on the Eastern Shores area of the iSimangaliso Wetland Park. It has held international status as a UNESCO World Heritage Site since 1999 (Taylor et al., 2006) and falls within the St Lucia Ramsar Site designated in 1986 (Taylor, 1991). It is one of the largest protected aquatic systems in southern Africa and, due to its biodiversity and natural beauty, has become an international tourist destination and is now a 'regional economic hub' (Whitfield and Taylor, 2009).

The Eastern Shores area has a subtropical climate and lies in a summer rainfall area (Schulze et al., 2008). It has been reported that 'the rainfall gradient westwards from the coast is strong, with a precipitation at Mission Rocks on the Indian 
Ocean coastal barrier dune exceeding $1200 \mathrm{~mm} \mathrm{yr}^{-1}$ and decreasing to around $900 \mathrm{~mm} \mathrm{yr}^{-1}$ at Fanies Island on the western shoreline of the estuary' (Taylor et al., 2006). However, Lynch (2004) provides mean annual precipitation values of 1056, 844 and $910 \mathrm{~mm} \mathrm{a}^{-1}$ from the nearby Fanies Island, Charters Creek and St Lucia respectively from a 125-year raster database, and the Agricultural Research Council measured an average annual rainfall at St Lucia over a 22-year period of $975 \mathrm{~mm} \mathrm{a}^{-1}$ (ARC-ISCW, 2011). Clearly rainfall in the area is variable and figures depend on the length of the period in years over which the rainfall was measured and the particular location. During this study there was a wellreported drought in the region (Grundling et al., 2014).

The Eastern Shores area is flanked by the Indian Ocean to the east and Lake St Lucia to the west (Fig. 2a). It includes coastal dunes (dune forest) to the east, the Embomveni Dunes (grassland) to the west and the Mfabeni Mire as an interdunal drainage line through the middle. The perennial Nkazana Stream drains from the Mfabeni Mire, providing freshwater to Lake St Lucia. This stream was recognised by Vrdoljak and Hart (2007) as an ecologically important source of freshwater to Lake St Lucia during droughts. Clulow et al. (2013) state that 'Organic matter and sediment have accumulated in the Mfabeni Mire over the past 45000 years, forming one of South Africa's largest peatlands and one of the oldest active peatlands in the world (Grundling et al., 1998)'. The Mfabeni Mire is approximately $8 \mathrm{~km}$ long (north-south direction) and $4 \mathrm{~km}$ wide in places (east-west direction). It comprises of subtropical freshwater wetland (SFW) with vegetation described by Vaeret and Sokolic (2008) and with a variable canopy height averaging approximately $0.8 \mathrm{~m}$ (Clulow et al., 2012). The Nkazana PSF is the other dominant vegetation type that runs down the western side of the Mfabeni Mire (Fig. 2b). The Nkazana PSF falls within the Indian Ocean Coastal Belt Biome, and is described as being a 'mixed, seasonal grassland community' (Mucina and Rutherford, 2006). The Nkazana PSF is further classified by von Maltitz et al. (2003) and Mucina and Rutherford (2006) as an Azonal Forest, indicating its presence due to, and reliance on, the ground water surface within the Mfabeni Mire.

\subsection{Site description}

The Swamp Forest site $\left(28^{\circ} 10.176^{\prime} \mathrm{S}, 32^{\circ} 30.070^{\prime} \mathrm{E}\right)$ posed significant logistical challenges due to the $20 \mathrm{~m}$ high tree canopy, thick undergrowth, soft ground, dangerous animals and general inaccessibility by road. The measurements were concentrated at its widest point (approximately $1 \mathrm{~km}$ ) to maximise the fetch for the flux measurements above the tree canopy. Clulow et al. (2013) described previous botanical research, explaining the structure of the Nkazana PSF and the vegetation in the vicinity of the research site as follows:

Wessels (1997) classified the swamp forests of the area into three logical subgroupings based on dom- inant species, stand density and basal areas. The Syzygium cordatum subgroup is characterised by an irregular, broken canopy of predominantly Syzygium cordatum trees (known locally as the Water Berry) of up to $30 \mathrm{~m}$, emerging above an intermediate canopy of approximately 6-15 m. Dominant tree species found in the Swamp Forest and in the vicinity of the site included: Macaranga capensis, Bridelia macrantha, Tarenna pavettoides and Stenochlaena tenuifolia. An impenetrable fern (Nephrolepis biserrata) covers the forest floor with a height of approximately $2.5 \mathrm{~m}$ and the Stenochlaena tenuifolia (Blechnaceae) fern grows up the tree stems to a height of approximately $10 \mathrm{~m}$.

The layer of peat at the Nkazana PSF site was approximately $2 \mathrm{~m}$ thick and underlain by sand. The water table depth was $<1.0 \mathrm{~m}$ but at the surface in low-lying areas of the forest. The leaf area index (LAI-2200, LI-COR Inc., Lincoln, Nebraska, USA) beneath the ferns and trees was approximately 7.2 and below the trees approximately 3.3.

\section{Materials and methods}

\subsection{Micrometeorological measurements}

An automatic weather station provided supporting meteorological data (Fig. 1). It was located adjacent to the Nkazana PSF in the Mfabeni Mire over a reed, sedge and grass dominated vegetation, described broadly as SFW (Fig. 2b). Observations of rainfall (TE525, Texas Electronics Inc., Dallas, TX, USA), air temperature and relative humidity (HMP45C, Vaisala Inc., Helsinki, Finland), solar irradiance (LI-200X, LI-COR, Lincoln, NB, USA), net irradiance (NRLite, Kipp and Zonen, Delft, The Netherlands), wind speed and direction (Model 03002, R. M. Young, Traverse City, MI, USA) were made every $10 \mathrm{~s}$. The appropriate statistical outputs were stored on a data logger (CR1000, Campbell Scientific Inc., Logan, UT, USA) at 30 min intervals. Sensors were installed according to recommendations of the World Meteorological Organisation (WMO, 2008) with the rain gauge orifice at $1.2 \mathrm{~m}$ and the remaining sensors $2 \mathrm{~m}$ above the ground. Vapour pressure deficit (VPD) was calculated on the data logger from air temperature $\left(T_{\text {air }}\right)$ and relative humidity $(\mathrm{RH})$ measurements according to Savage et al. (1997).

\subsection{Measurement of energy fluxes and actual total evaporation}

The shortened energy balance equation is commonly used in evaporation studies (Drexler et al. 2004) to describe the partitioning of energy at the Earth's surface and provides an indirect method to determine $\mathrm{ET}_{\mathrm{a}}$ (Eq. 1). The 'shortened' version ignores those energies associated with photosynthe- 


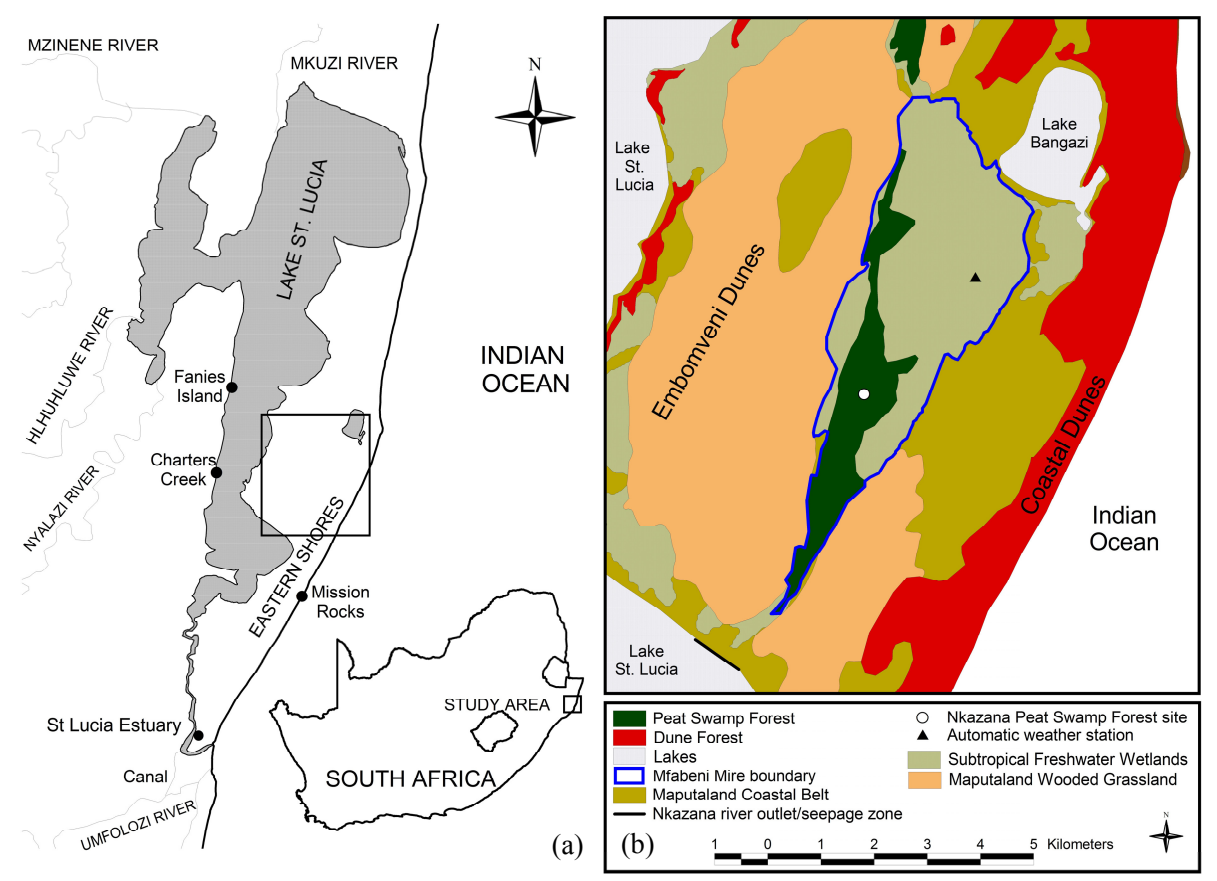

Figure 2. (a) Location of the Eastern Shores within South Africa, (b) the Nkazana Peat Swamp Forest site (where the EC and sap-flow systems were located) and the automatic weather station within the Mfabeni Mire on the Eastern Shores (data from Mucina and Rutherford, 2006).

sis, respiration and energy stored in plant canopies. However, these are considered small when compared with the other terms (Thom, 1975). The shortened energy balance equation is written as

$R_{\mathrm{n}}=G+H+\mathrm{LE}$,

where $R_{\mathrm{n}}$ is the net irradiance, $H$ is the sensible heat flux, $G$ is the ground heat flux and LE is the latent energy flux, which is the energy equivalent of evaporation by conversion (Savage et al., 2004).

Eddy covariance is based on the estimation of the eddy flux which is expressed as:

$F=\rho_{d} \overline{w^{\prime} s^{\prime}}$

where $\rho_{d}$ is the density of dry air, $w$ is vertical wind speed (measured with the sonic anemometer described below) and $s$ is the concentration of the scalar of interest (water vapour in this case). The primes indicate fluctuation from a temporal average (i.e. $w^{\prime}=w-\bar{w} ; s^{\prime}=s-\bar{s}$ ) and the overbar represents a time average. The averaging period of the instantaneous fluctuations, of $w^{\prime}$ and $s^{\prime}$ should be long enough (30 to $60 \mathrm{~min}$ ) to capture all of the eddy motions that contribute to the flux and fulfil the assumption of stationarity (Meyers and Baldocchi, 2005).

The vertical flux densities of $H\left(\mathrm{ET}_{\mathrm{a}}\right.$ derived indirectly by the shortened energy balance equation) and $\mathrm{LE}\left(\mathrm{ET}_{\mathrm{a}}\right.$ derived directly) were estimated by calculating the mean covariance of sensible (Eq. 2) and water vapour fluctuations respectively, with fluctuating vertical velocity (Baldocchi et al., 1988).

Soil heat flux was measured using two soil heat flux plates (HFT-3, REBS, Seattle, WA, USA) and a system of parallel thermocouples (Type E). The plates were placed at a depth of $0.08 \mathrm{~m}$ below the peat surface. The thermocouples were buried at 0.02 and $0.06 \mathrm{~m}$ and were used together with volumetric water content (CS615, Campbell Scientific Inc., Logan, UT, USA) in the upper $0.06 \mathrm{~m}$ to estimate the heat stored above the soil heat flux plates. The measurements were stored every $10 \mathrm{~s}$ on a data logger (CR23X, Campbell Scientific Inc., Logan, UT, USA) and 30 min averages were computed. During the measurements at the Nkazana Swamp Forest, the groundwater level was deeper than $0.1 \mathrm{~m}$ below the surface and therefore, the total $G$ was determined using the calorimetric methodology described by Tanner (1960).

Over the corresponding time period, $R_{\mathrm{n}}$ was measured above the forest canopy, using a $21.3 \mathrm{~m}$ telescopic mast (WT6, Clark Masts Systems Ltd, Isle of Wight, UK). It was erected within the forest, on a fallen tree stump approximately $2.5 \mathrm{~m}$ high (Fig. 3a). This formed a firm base for the $90 \mathrm{~kg}$ mast which was carried into the forest from the nearest road approximately $1 \mathrm{~km}$ away. The computer box for the EC system (In Situ Flux Systems AB, Ockelbo, Sweden) was installed near the base of the mast (Fig. 3b) and a generator that automatically charged a bank of four $100 \mathrm{Ah}$ deep-cycle lead-acid batteries (accumulators) was positioned approximately $50 \mathrm{~m}$ from the site in a predominantly downwind di- 


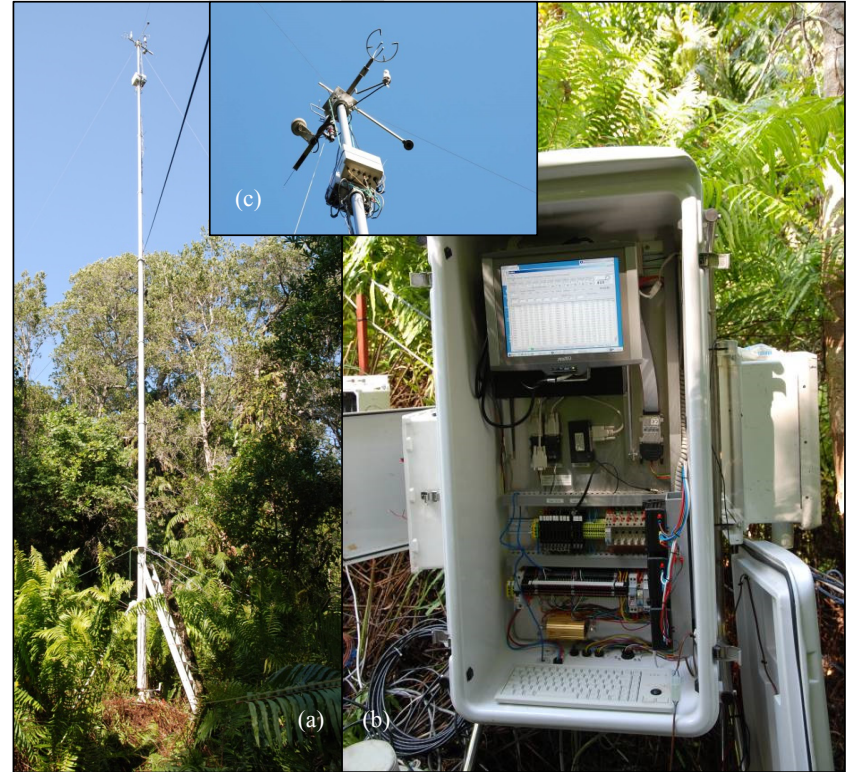

Figure 3. (a) Telescopic mast $(21.3 \mathrm{~m})$ erected in the swamp forest to raise the eddy covariance instruments above the forest canopy, (b) the computer installed at the swamp forest, housed in a temperature controlled enclosure and (c) the instruments attached to the head of the mast.

rection (the northwest) to minimise any possible influence from the exhaust fumes on the flux measurements. The generator was controlled by a logger (CR10X, Campbell Scientific Inc., Logan, UT, USA) which was set to activate the charging system (220VAC petrol generator and $40 \mathrm{~A} 12 \mathrm{~V}$ charger) when the accumulators dropped below $12.4 \mathrm{~V}$.

A 'SATI-3VX' style, three-dimensional (3-D) sonic anemometer (Applied Technologies, Inc., Longmont, CO, USA) and open-path infrared gas analyser (LI7500, LI-COR, Lincoln, NE, USA) were mounted on the head of the mast $(0.089 \mathrm{~m}$ diameter) orientated to face the east (predominant wind direction) to avoid air-flow distortion from the mast (Fig. 3c). In addition, $T_{\text {air }}$ (PT-10, Peak Sensors Ltd, Chesterfield, UK) and $R_{\mathrm{n}}$ (NRLite, Kipp and Zonen, Delft, the Netherlands) were measured at the head of the mast. Data collection and analyses of the system was made in real time by the ECOFLUX software fully described by Grelle and Lindroth (1996) using a Flux Computer (In Situ Flux Systems AB, Ockelbo, Sweden). The system operated with a sampling rate of $10 \mathrm{~Hz}$ and the average fluxes were calculated every $30 \mathrm{~min}$. The raw data were also stored for further processing. All the necessary corrections for air-density effects and 3-D coordinate rotation were performed on the Flux Computer to determine $H$ (Grelle and Lindroth, 1996).

The Bowen ratio $(\beta)$ has historical significance in evaporation studies and is defined as

$$
\beta=\frac{H}{\mathrm{LE}}
$$

for a specified time period (Bowen, 1926). It informs on the dominance of $H$ or LE and was calculated at a daily time interval in this study, providing a useful means of showing changes in the distribution and weighting of the energy balance components within and between field campaigns.

\subsection{Energy balance closure}

If each component of the energy balance is measured accurately and independently, then Eq. (1) should be satisfied, and closure is considered satisfied. However, energy balance closure could still be achieved if two or more terms have incorrect values and the terms in Eq. (1) still sum to zero (Savage et al., 2004). If the components of the shortened energy balance equation are measured independently then $R_{\mathrm{n}}-G-H-\mathrm{LE}=c$, where $c$ is termed the energy balance closure $\left(\mathrm{W} \mathrm{m}^{-2}\right)$, and closure is satisfied if $c=0 \mathrm{~W} \mathrm{~m}^{-2}$. By rearranging Eq. (1), closure is not achieved if the available energy $R_{\mathrm{n}}-G$ does not equal the turbulent fluxes $H+$ LE. Another measure of the lack of closure is the closure ratio or the energy balance closure discrepancy $D$ defined by Twine et al. (2000) as

$D=\frac{H+\mathrm{LE}}{R_{\mathrm{n}}-G}$,

in which a $D$ of 1 indicates perfect closure. Several studies using numerous techniques over various surfaces have failed to achieve closure by up to 20 or $30 \%$ (Wilson et al., 2001, 2002; Barr et al., 2006). The vast majority have found higher energy input by radiation fluxes than loss by turbulent fluxes ( $H$ and LE) and $G$ (Oncley et al., 2007). Therefore, the measured fluxes should be corrected or the uncertainties in the measured fluxes accepted (Twine et al., 2000). Several reasons for lack of energy balance closure have been discussed by Twine et al. (2000), Wilson et al. (2002), and Cava et al. (2008). These reasons include: (1) sampling errors associated with different measurement source areas for the terms in Eq. 1, (2) a systematic bias in instrumentation, (3) neglected energy sinks, (4) the loss of low- and/or highfrequency contributions to the turbulent flux, (5) neglected advection of scalars, (6) measurement errors related to sensor separation, alignment problems, interference from tower or instrument-mounting structure, and (7) errors in the measurement of $R_{\mathrm{n}}$ and/or $G$. Despite concerns that the direct method of determining total evaporation $\left(\mathrm{ET}_{\mathrm{ec}}\right)$ by measuring water vapour concentrations using an Infrared Gas Analyser may result in underestimates or overestimates of LE, in this study, it was considered that some of the closure pitfalls of the shortened energy balance method, such as (3) and (7) in particular, could be significant due to the tall canopy at the site (3) and point measurement location (7). Therefore, all $\mathrm{ET}_{\mathrm{a}}$ results reported in this paper were calculated by the direct method. Energy balance closure discrepancy was determined during the daytime period $\left(R_{\mathrm{n}}>0\right)$ due to 
the potentially large nocturnal influences reported by Wilson et al. (2002).

\subsection{Measurement of tree sap flow}

A heat pulse velocity system based on the heat ratio method (Burgess et al., 2001) was used to measure sap flow at various depths across the sapwood of two trees over 20 months from September 2009 to early May 2011 which overlapped with the November 2009 and March 2010 field campaigns (Fig. 1). The trees measured were located approximately $40 \mathrm{~m}$ from the mast where the EC and energy balance sensors were installed. Representative trees, in terms of species, stem diameter, canopy height and proximity to each other, were selected given the cable length limitations of the HPV system. The Syzigium cordatum tree selected was approximately $22.5 \mathrm{~m}$ tall and had a breast height stem diameter of $0.430 \mathrm{~m}$. Sap flow was measured at four depths across the sapwood on both the eastern and western sides of the stem to account for differences in the sapwood depth around the tree. Sap flow was also measured in a nearby understory tree (Shirakiopsis elliptica) with a smaller stem diameter $(0.081 \mathrm{~m})$ at four depths within the sapwood. Air temperature and relative humidity (HMP45C, Vaisala Inc., Helsinki, Finland) within the canopy, at a height of $2 \mathrm{~m}$ above the ground, and soil volumetric water content $(\theta)$ at the Syzigium cordatum tree (where the roots were most dense at a depth of $0.075 \mathrm{~m}$ ) were also measured. These were recorded hourly to coincide with the sap-flow measurements. Further details of the installation, equipment used, wounding corrections applied and calculations to derive the tree sap flow are documented in Clulow et al. (2013). In this paper, following Dye et al. (2008), sap flow is assumed to equate with tree transpiration and tree water-use.

\subsection{Modelling actual total evaporation from sap flow}

Polynomial regression (second order) analysis in the Genstat software (VSN International, 2011) was used to describe the relationship between measured $\mathrm{ET}_{\mathrm{a}}$ and sap flow of the emergent and understory trees during the overlapping periods of the November 2009 and March 2010 field campaigns in order to understand the possibility of extending the record of $\mathrm{ET}_{\mathrm{a}}$ from the Nkazana PSF using the long-term sap-flow records. The hourly $\mathrm{ET}_{\mathrm{a}}$ and sap-flow data were checked for homoscedasticity and required a square root transformation to correct the variance distribution. The model derived was applied over a full year of sap-flow data (October 2009 to September 2010) to obtain an annual $\mathrm{ET}_{\mathrm{a}}$ (Fig. 1).

\subsection{Evaporation models assessed}

Two well-recognised evaporation models were tested for applicability of modelling $\mathrm{ET}_{\mathrm{a}}$ from the Nkazana PSF (Fig. 1). After assessment of the models at an hourly temporal resolution, over the three field campaigns, the most applicable model was applied to the long-term $\mathrm{ET}_{\mathrm{a}}$ discussed above and verified using historic data collected by the Council for Scientific and Industrial Research (CSIR) during a preliminary study over the Nkazana PSF from 8 to 12 August 2008 and 12 to 20 November 2008 (unpublished). The CSIR measured $\mathrm{ET}_{\mathrm{a}}$ with the identical EC equipment used during the field campaigns in 2009 and 2010 described above and at the same site in the Nkazana PSF making the data ideal for verification of the models.

\subsubsection{FAO Penman-Monteith reference evaporation}

The original Penman evaporation model (Penman, 1948), assumed an absence of any control on evaporation at the Earth's surface - in effect, an open water or wet surface situation. This was extended by Monteith (1965) to incorporate surface and aerodynamic resistance functions applicable to vegetated surfaces and was widely used in this form as the Penman-Monteith model. It is however, highly data intensive (Mao et al., 2002; Drexler et al., 2004) and the model was therefore standardised by the Food and Agriculture Organisation in Irrigation and Drainage Paper No. 56 (Allen et al., 1998) into a form known as the FAO56 Penman-Monteith model that could be applied at both hourly and daily time intervals. The model received favourable acceptance internationally in establishing a reference evaporation $\left(\mathrm{ET}_{\mathrm{o}}\right)$ index (atmospheric evaporative demand) as a function of weather variables measured at most standard weather station systems. The definition of a reference crop over which the weather variables should be measured was a 'hypothetical crop with an assumed height of $0.12 \mathrm{~m}$ having a surface resistance of $70 \mathrm{~s} \mathrm{~m}^{-1}$ and an albedo of 0.23 , closely resembling the evaporation of an extensive surface of green grass of uniform height, actively growing and adequately watered' (Allen et al., 1998). A nearby crop $\mathrm{ET}_{\mathrm{a}}$ is calculated by adjusting $\mathrm{ET}_{\mathrm{o}}$ by a crop factor $\left(K_{\mathrm{c}}\right)$ in the form

$\mathrm{ET}_{\mathrm{a}}=\mathrm{ET}_{\mathrm{o}} \cdot K_{\mathrm{c}}$,

where the crop is not water stressed. In Allen et al. (1998), values of $K_{\mathrm{c}}$ have been compiled for different vegetation types at different stages in crop development. Since recommendations by the American Society of Civil Engineers Evapotranspiration in Irrigation and Hydrology Committee (Allen, et al., 2000) and the work by Irmak et al. (2005) and Allen et al. (2006) amongst others, the tall crop reference (alfalfa height $=0.5 \mathrm{~m})$ and separate daytime $\left(r=50 \mathrm{~s} \mathrm{~m}^{-1}\right)$ and night-time $\left(r=200 \mathrm{~s} \mathrm{~m}^{-1}\right)$ resistances for hourly calculations were introduced. It was this most recent form of the equation, now referred to as the FAO Penman-Monteith $\mathrm{ET}_{\mathrm{o}}$, that was applied in the current study.

Using the FAO Penman-Monteith $\mathrm{ET}_{\mathrm{o}}$ in combination with the long-term $\mathrm{ET}_{\mathrm{a}}$ (from sap flow), $K_{\mathrm{c}}$ was calculated (Eq. 5) for the Nkazana PSF at an hourly interval (while $R_{\mathrm{n}}>0$ and $\mathrm{ET}_{\mathrm{a}}>0.1 \mathrm{~mm} \mathrm{~h}^{-1}$ ) and summed to daily totals as recommended by Irmak et al. (2005). The reference evapora- 
tion approach has been successful internationally, partly due to technological advances leading to improvements in temporal and spatial data availability, but also because it provides a method for estimating $\mathrm{ET}_{\mathrm{a}}$, which is transferrable and can be applied to different vegetation types and locations across the world.

\subsubsection{Priestley-Taylor potential evaporation}

Priestley and Taylor (1972) simplified the theoretical Penman equation for specific conditions. They reasoned that, as an air mass moves over an expansive, short, well-watered canopy, evaporation would eventually reach a rate of equilibrium. In this case, where humid air moves over a wet surface, the aerodynamic resistances become negligible, while irradiance dominates, and the rate of evaporation would be equal to the potential evaporation $\left(\mathrm{ET}_{\mathrm{p}}\right)$ which is written as

$\mathrm{ET}_{\mathrm{p}}=\frac{\alpha}{L_{\mathrm{v}}} \cdot \frac{\Delta}{\Delta+\gamma} \cdot\left(R_{\mathrm{n}}-G\right)$,

where $\alpha$ is a constant, $L_{\mathrm{V}}$ is the specific latent heat of vaporisation of water $\left(2.45 \mathrm{MJ} \mathrm{kg}^{-1}\right), \Delta$ is the slope of the saturation water vapour pressure versus $T_{\text {air }}$, and $\gamma$ is the psychometric constant.

The definition of the Priestley-Taylor model makes it suitable for estimation of evaporation from open water areas and wetlands (Price, 1992; Souch et al., 1996; Mao et al., 2002) but it has been applied over numerous other surfaces such as forests (Shuttleworth and Calder, 1979), cropped surfaces (Davies and Allen, 1973; Utset et al., 2004), pastures (Sumner and Jacobs, 2005) and even soil water limited conditions in forest clearcuts (Flint and Childs, 1991) with varied success and deviations from the originally proposed estimate for $\alpha$ of 1.26. In this study it was applied in the form described by Savage et al. (1997) where $\Delta /(\Delta+\gamma)$ was estimated by

$$
\frac{\Delta}{\Delta+\gamma}=0.413188419+0.0157973 \cdot T_{\mathrm{air}}-0.00011505 \cdot T_{\mathrm{air}}^{2},
$$

where $T_{\text {air }}$ is average air temperature over the interval of calculation (hourly in this study). By rearranging Eq. (6), and substituting $\mathrm{ET}_{\mathrm{a}}$ for $\mathrm{ET}_{\mathrm{p}}, \alpha$ was estimated in the same way as $K_{\mathrm{c}}$ above.

\subsection{Investigating climatic controls and drivers of sap flow}

Sap flow was compared by simple linear regression to climatic variables (Fig. 1) generally considered to control sap flow in trees such as solar irradiance $\left(I_{\mathrm{S}}\right)$ and VPD (Albaugh et al., 2013). Sap flow was also compared by multiple regression analysis to the micrometeorological parameters including $I_{\mathrm{s}}, T_{\mathrm{air}}, \mathrm{RH}$ and soil volumetric water content $(\theta)$ to determine individual and combined drivers of sap flow. The log of the sap-flow measurements was modelled, as the variance of the measurements themselves was not homoscedastic and therefore required a variance stabilising transformation. Significance of variables, with up to four-way interactions were considered. In addition, the predictor variables $\left(I_{\mathrm{s}}, \mathrm{RH}, T_{\text {air }}\right.$ and $\theta$ ) were broken up into sets of data with different ranges using regression tree analysis. In regression tree analysis a different model is applied to individual ranges of data rather than a global model (such as in regression analysis), in which a single model is applied to the entire range of each variable. The relationship for a linear regression model is assumed to be the same no matter what the value of any of the predictor variables is. The consequence thereof, is that a good midday relationship between sap-flow and a variable (such as $I_{\mathrm{S}}$ ) for example, may be missed due to a poor relationship during the early morning and late afternoon periods. The regression tree analysis provides an alternative approach, in which the predictor variables are broken up into different sets, and a different model applied to each individual set. In the regression tree analysis output, which is represented by a hierarchical tree diagram - the longer the line, the greater the difference between the two subsets, and the higher in the hierarchy a split occurs, the more significant is the split.

\section{Results}

\subsection{Weather conditions during the study}

The daily radiant densities (integrated solar irradiance over a day) were lowest in August $2009\left(\sim 15 \mathrm{MJ} \mathrm{m}^{-2}\right)$ and most consistent (Table 1), whereas in November 2009 and March 2010 they were higher and more variable (between $\sim 16$ and $\sim 25 \mathrm{MJ} \mathrm{m}^{-2}$ ), particularly in November 2009 (Table 1). The daily maximum temperatures were highest in March 2010 $\left(\sim 29^{\circ} \mathrm{C}\right)$ and lowest in August $2009\left(22.8^{\circ} \mathrm{C}\right)$. Average minimum RH was lowest in August $2009(\sim 34 \%)$ and the average daytime VPD was highest $(1.2 \mathrm{kPa})$. Average daily wind speeds were notably high in November $2009\left(>7 \mathrm{~m} \mathrm{~s}^{-1}\right)$ and the dominant wind direction for the site was from the northeast and the south. Some rainfall $(<7 \mathrm{~mm})$ occurred during the field campaigns but fortunately fell at night and did not affect the daytime flux measurements.

The microclimate within the Nkazana PSF was noticeably different to the adjacent SFW areas. The VPD within the Nkazana PSF canopy was consistently lower than the SFW where the automatic weather station was located approximately $3 \mathrm{~km}$ away, with the larger differences occurring from March to August, which is the winter period (Fig. 4). A difference in dawn $T_{\text {air }}$ between the Nkazana PSF and the adjacent area was also noted. The difference was lowest in summer and highest in winter with the Nkazana PSF being up to $6{ }^{\circ} \mathrm{C}$ warmer on some mornings in June 2010 . 
Table 1. Summary of weather conditions during the August 2009, November 2009 and March 2010 field campaigns.

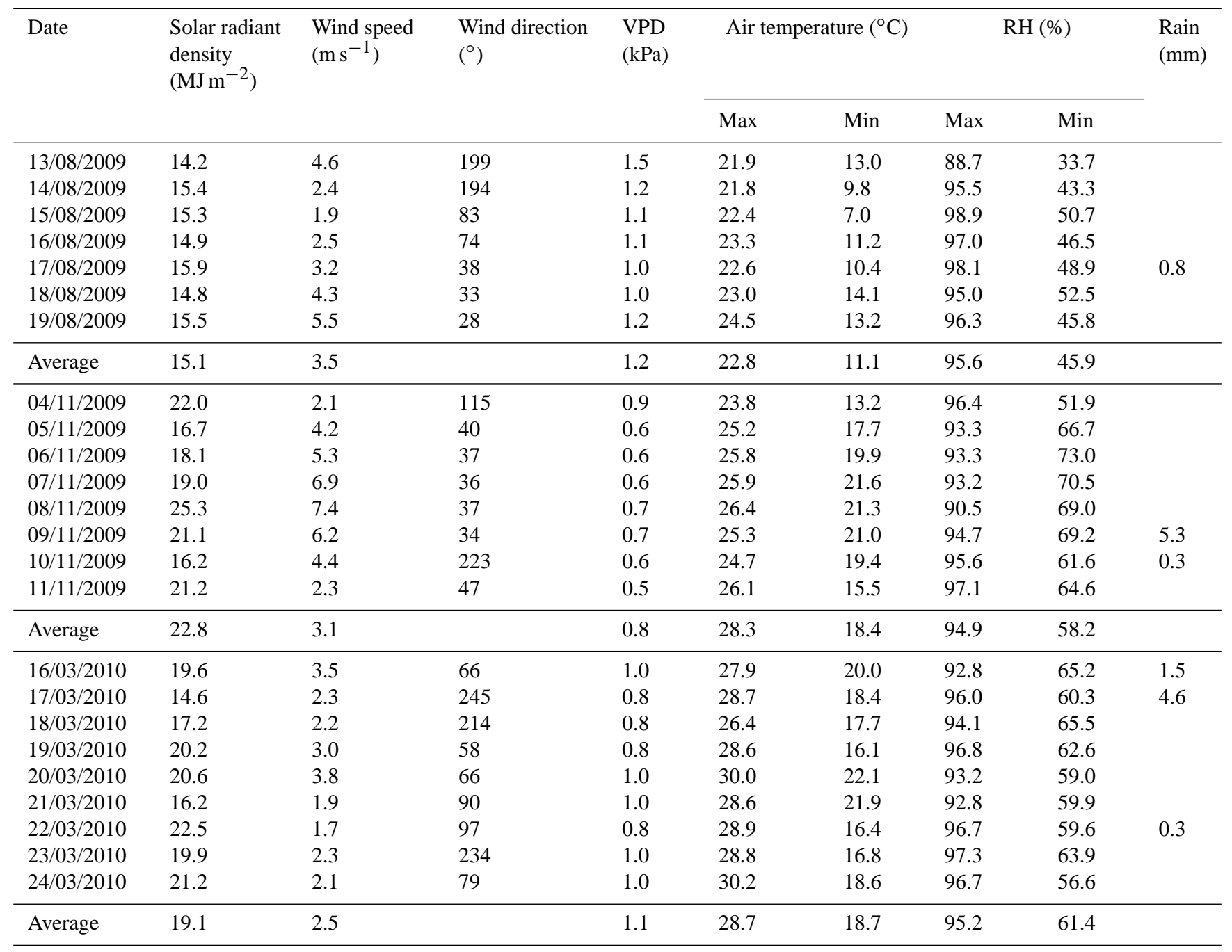

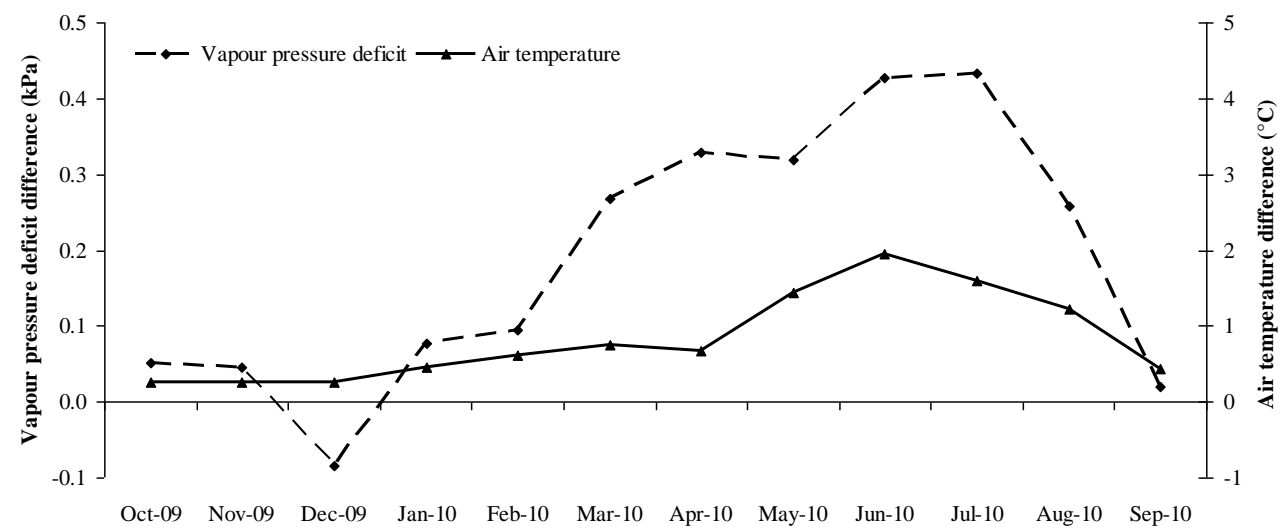

Figure 4. The difference in the monthly daytime (09:00 LT to 15:00 LT) vapour pressure deficit and difference between the monthly average dawn air temperatures measured in the subtropical freshwater wetland area of the Mfabeni Mire (reeds, sedges and grasses) and within the canopy of the Nkazana Peat Swamp Forest site. 

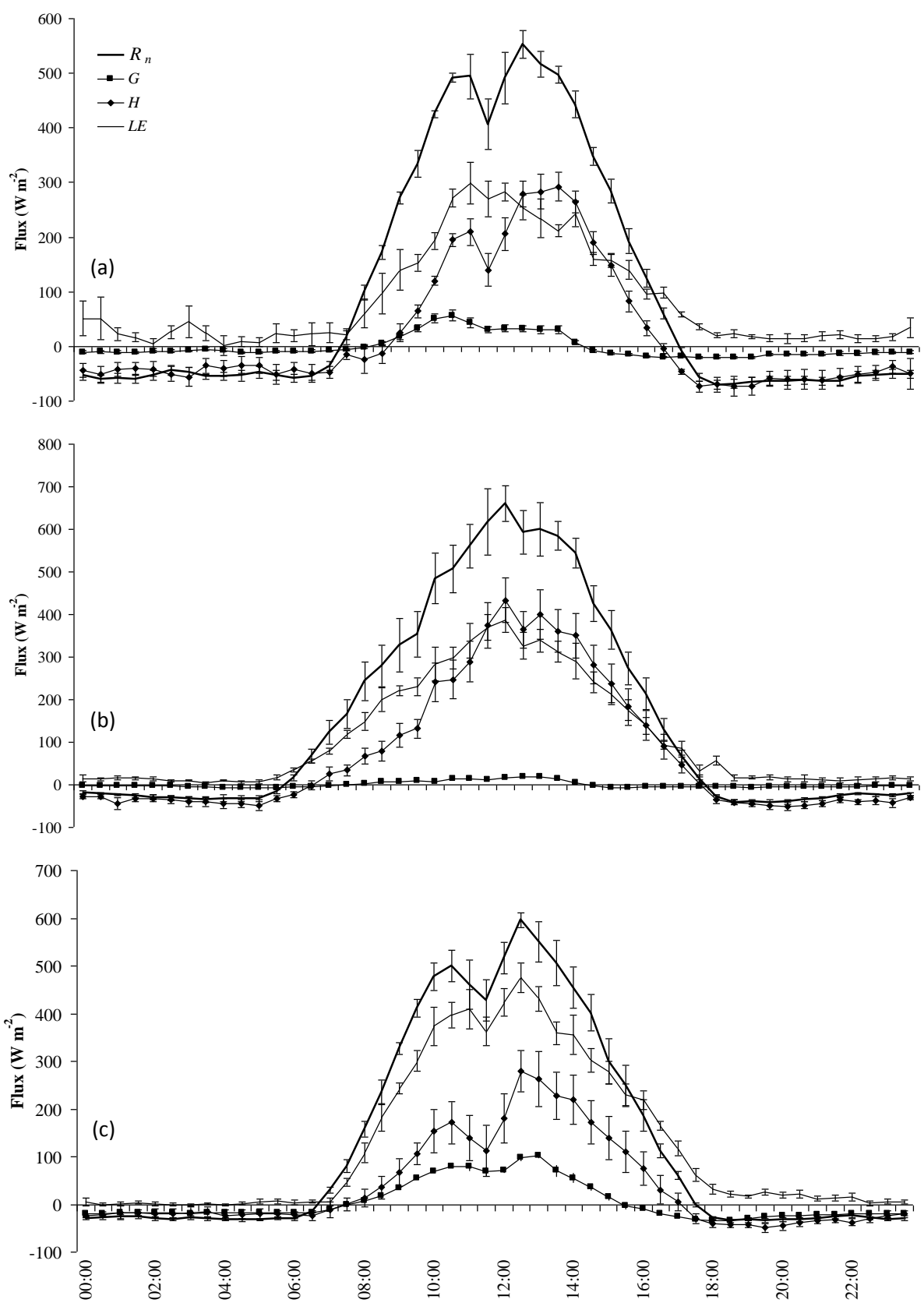

Figure 5. The average of the half-hourly energy fluxes, with error bars indicating the standard error, measured at the Nkazana Swamp Forest in (a) August 2009, (b) November 2009 and (c) March 2010.

\subsection{Eddy covariance flux measurements}

Despite the apparent consistency in the daily radiant density during August 2009 noted above (Table 1), the $30 \mathrm{~min}$ net irradiance flux data showed that all field campaigns were affected by cloud during the daytime, as indicated by the standard error bars of the net irradiance (Fig. 5a, b and c). Even the August 2009 data, despite being in the middle of the dry season, were influenced by cloud during 6 out of the 7 days of measurement (not shown). During the August 2009 and
March 2010 field campaigns, there was a noticeable dip in the average $R_{\mathrm{n}}$ at approximately 11:00 LT. with large standard errors $\left(>90 \mathrm{~W} \mathrm{~m}^{-2}\right)$ due to cloud cover. In November, the dip occurred at approximately 13:00 LT., also accompanied by large standard errors $\left(>90 \mathrm{~W} \mathrm{~m}^{-2}\right)$. The cloud affected pattern of $R_{\mathrm{n}}$ was translated through to $H$ and LE, which were positive during the day, and with largest standard errors coinciding with those of the $R_{\mathrm{n}}$ except for the early morning observed LE in August 2009, which was attributed to the evaporation of dew on some days. The max- 

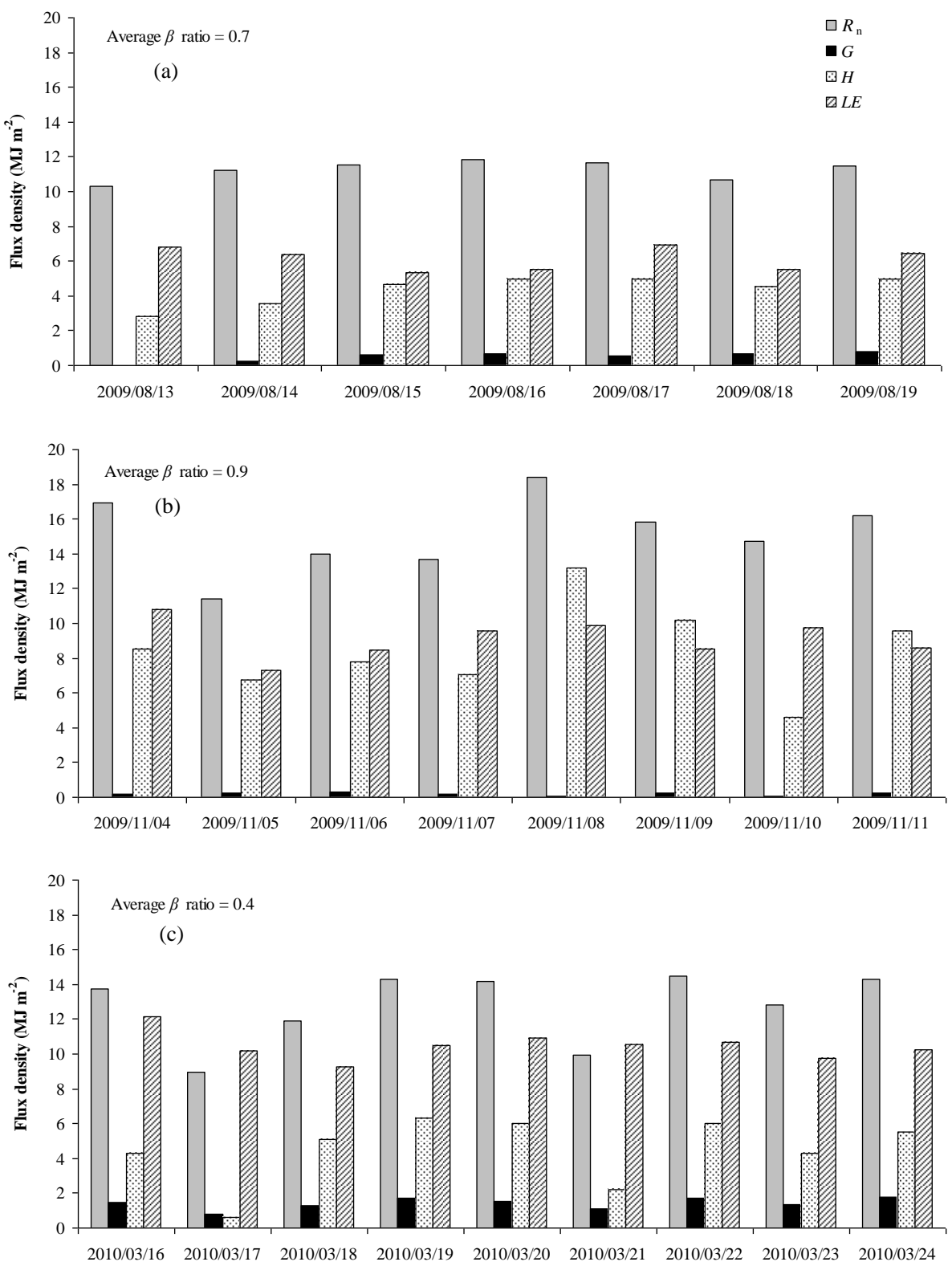

Figure 6. Daily total energy densities (while $R_{\mathrm{n}}>0$ ) measured at the Nkazana Swamp Forest in (a) August 2009, (b) November 2009 and (c) March 2010

imum rates of LE were approximately $400 \mathrm{~W} \mathrm{~m}^{-2}$ in August $2009,600 \mathrm{~W} \mathrm{~m}^{-2}$ in November 2009 and $700 \mathrm{~W} \mathrm{~m}^{-2}$ in March 2010 (not shown). The pattern of $G$ fluctuated diurnally but due to attenuation (sensors were below the soil surface) the pattern was smoother than the other fluxes during the course of the day.

During the August 2009 field campaign the daily net radiant density, between 10.2 and $11.8 \mathrm{MJ} \mathrm{m}^{-2}$, was reasonably consistent at a daily level (Fig. 6a), despite the irregularity observed from the $30 \mathrm{~min}$ data. During the November 2009 (11.4 to $18.3 \mathrm{MJ} \mathrm{m}^{-2}$ ) and the March 2010 (9.0 to $14.4 \mathrm{MJ} \mathrm{m}^{-2}$ ) field campaigns, the daily net radiant density was more variable (Fig. $6 \mathrm{~b}$ and c). This variability at a daily level was translated through to the $H$ and LE results, which during August 2009 were fairly consistent, but irregular during November 2009 and March 2010. The average daily net radiant density was lowest in August $2009\left(11.2 \mathrm{MJ} \mathrm{m}^{-2}\right)$, highest in November $2009\left(15.1 \mathrm{MJ} \mathrm{m}^{-2}\right)$ and in-between during March $2010\left(12.7 \mathrm{MJ} \mathrm{m}^{-2}\right)$. The average daily soil heat flux did not mirror the pattern of $R_{\mathrm{n}}$ and was highest in March 2010 at approximately $11 \%$ of $R_{\mathrm{n}}$ (up to $1.8 \mathrm{MJ} \mathrm{m}^{-2}$ ), lower in August 2009 at $5 \%$ of $R_{\mathrm{n}}\left(0.7 \mathrm{MJ} \mathrm{m}^{-2}\right)$ and lowest in November 2009 at $1 \%$ of $R_{\mathrm{n}}$ (up to $0.3 \mathrm{MJ} \mathrm{m}^{-2}$ ). 


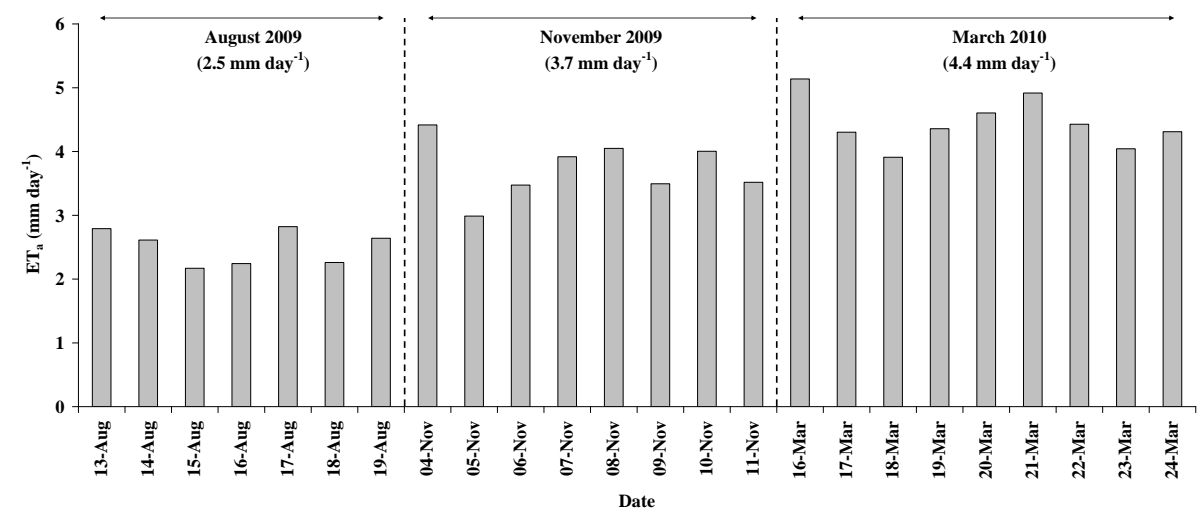

Figure 7. Daily actual total evaporation $\left(\mathrm{ET}_{\mathrm{a}}\right)$ measured over the Nkazana Swamp Forest during three representative periods.

The daily total LE was higher than $H$ in August 2009 (Fig. 6a), with a daily average $\beta$ ratio of 0.7 (0.4 to 0.9 ). In November 2009 (Fig. 6b) the daily average $\beta$ ratio was higher with a daily average of 0.9 (0.5 to 1.3$)$ but in March (Fig. 6c) however, LE dominated the energy balance with an average $\beta$ ratio of 0.4 (0.1 to 0.6 ).

Closure discrepancy was different for each field campaign. In August 2009 the $D$ was 0.98 indicating exceedingly good closure. However, the second and third field campaigns produced a $D$ of 1.18 and 1.33 in November 2009 and March 2010, respectively, indicating (1) either an overestimation of LE and/or $H$, and/or an underestimation of the available energy $\left(R_{\mathrm{n}}-G\right)$ and/or (2) unaccounted energy such as advection or storage in the canopy biomass.

\subsection{Measured actual total evaporation}

The mean daily $\mathrm{ET}_{\mathrm{a}}$ over the three field campaigns was significantly different (based on their $95 \%$ confidence interval). The daily $\mathrm{ET}_{\mathrm{a}}$ (Fig. 7) was lowest in the August 2009 (winter) and increased progressively through November 2009 (early summer) to March 2010 (late summer). The standard deviation (SD) for all field campaigns was similar ( 0.3 to $0.4 \mathrm{~mm}$ ) but the coefficient of variation (not shown) differed with the highest in November 2009 (12.0) and August 2009 (11.0) and lowest in March 2010 (8.8).

\subsection{Relationship between sap flow and actual total evaporation measured during two field campaigns}

The diurnal courses of the sap flow from the emergent and understory trees were surprisingly smooth in comparison to the $\mathrm{ET}_{\mathrm{a}}$ results (Fig. 8a-d). The $\mathrm{ET}_{\mathrm{a}}$ is an integrated measure of soil evaporation and transpiration from numerous plants at different levels within the canopy over the contributing area described by the footprint, whereas the transpiration measurements (assumed to equal sap flow) describe the physiology of a single tree. The $R_{\mathrm{n}}$, frequently considered a significant driver of tree physiology, fluctuated due to cloud cover (Fig. 5a, b and c). These fluctuations were not translated into fluctuations in tree sap flow but are evident in the $\mathrm{ET}_{\mathrm{a}}$ results particularly over the midday period. A similar pattern was observed in the March 2010 ET $_{\mathrm{a}}$ data (Fig. 8c and d). It is recommended that $G$ be measured at numerous positions under swamp forest canopies in order to capture the variability in $G$ and a representative average.

Despite the greater midday variability of the $\mathrm{ET}_{\mathrm{a}}$ data, the polynomial regression (least squares) between hourly $\mathrm{ET}_{\mathrm{a}}$ and tree sap flow showed a strong relationship in November 2009 for the emergent tree $\left(\mathrm{RMSE}=0.05 \mathrm{~mm} \mathrm{~h}^{-1}\right.$ ) as well as the understory tree $\left(\mathrm{RMSE}=0.06 \mathrm{~mm} \mathrm{~h}^{-1}\right)$. The polynomial regression was convex $\left(R^{2}=0.89\right)$ rather than linear $\left(R^{2}=0.87\right)$ in the case of the emergent tree (Fig. 9a) and concave $\left(R^{2}=0.92\right)$ rather than linear $\left(R^{2}=0.90\right)$ in the case of the understory tree (Fig. 9b). The increase in the rate of sap flow of the emergent tree was exponential for lower values of $\mathrm{ET}_{\mathrm{a}}$ (morning and evening) but the rate of sap flow versus $\mathrm{ET}_{\mathrm{a}}$ for higher values of $\mathrm{ET}_{\mathrm{a}}$ slowed down as the tree reached its peak transpiration rate. In contrast the understory sap flow rate increased gradually per unit increase in $\mathrm{ET}_{\mathrm{a}}$ at lower values but at higher values of $\mathrm{ET}_{\mathrm{a}}$ the increase in sap flow was exponential. In March 2010 the results were similar with RMSEs of 0.07 and $0.08 \mathrm{~mm} \mathrm{~h}^{-1}$ for the emergent and understory trees, respectively. Convex and concave trend lines again fitted the data best (Fig. 9c and d). Lagging the sap flow by $1 \mathrm{~h}$ as suggested by Granier et al. (2000) did not improve the regression of sap flow on $\mathrm{ET}_{\mathrm{a}}$.

\subsection{Comparison of the FAO Penman-Monteith reference evaporation versus the Priestley-Taylor potential evaporation during the three field campaigns}

The linear regression (least squares) of the hourly $\mathrm{ET}_{\mathrm{o}}$ against hourly $\mathrm{ET}_{\mathrm{a}}$ explained 75,85 and $76 \%$ of the fluctuations in $\mathrm{ET}_{\mathrm{a}}$ during the August 2009, November 2009 and March 2010 field campaigns, respectively (Table 2). The Priestley-Taylor model did not perform as well, accounting for 54, 74 and $62 \%$ of the variation in $\mathrm{ET}_{\mathrm{a}}$ during the August 
Table 2. Summary of the hourly crop coefficient $K_{\mathrm{c}}$ and advective term $\alpha$ with standard deviation and root mean square error (RMSE) for each of the three field campaigns.

\begin{tabular}{lllllllll}
\hline \multicolumn{1}{c}{$K_{\mathrm{c}}$} & \multicolumn{3}{c}{$\alpha$} \\
\hline & $K_{\mathrm{c}}$ & $\begin{array}{l}\text { Coefficient of } \\
\text { determination }\end{array}$ & $\begin{array}{l}\text { Standard } \\
\text { deviation }\end{array}$ & RMSE & $\alpha$ & $\begin{array}{l}\text { Coefficient of } \\
\text { determination }\end{array}$ & $\begin{array}{l}\text { Standard } \\
\text { deviation }\end{array}$ & RMSE \\
\hline Aug 2009 & 0.8 & 0.75 & 0.22 & 0.07 & 1.0 & 0.54 & 0.35 & 0.08 \\
Nov 2009 & 1.0 & 0.85 & 0.17 & 0.07 & 1.0 & 0.74 & 0.34 & 0.11 \\
Mar 2010 & 1.3 & 0.76 & 0.39 & 0.11 & 1.1 & 0.62 & 0.46 & 0.13 \\
\hline
\end{tabular}
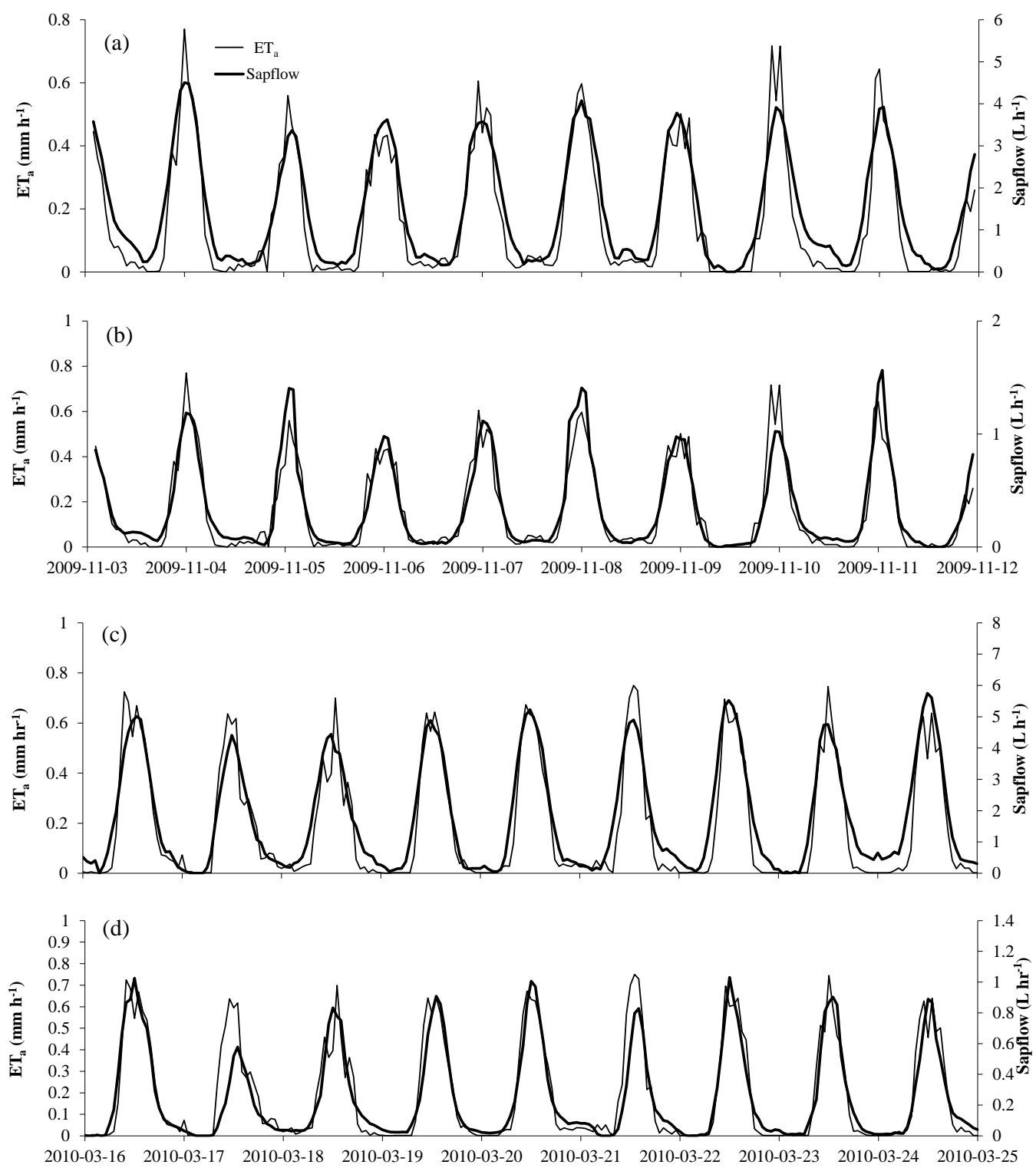

Figure 8. Diurnal course of the hourly actual total evaporation $\left(\mathrm{ET}_{\mathrm{a}}\right)$ and sap flow in November 2009 (a and b) and March 2010 (c and d) for the emergent and understory trees, respectively.

2009, November 2009 and March 2010 field campaigns, respectively (Table 2).
The slope of the linear regression $\left(K_{\mathrm{c}}\right)$ varied between field campaigns (Table 2) and was highest in March (1.3), 

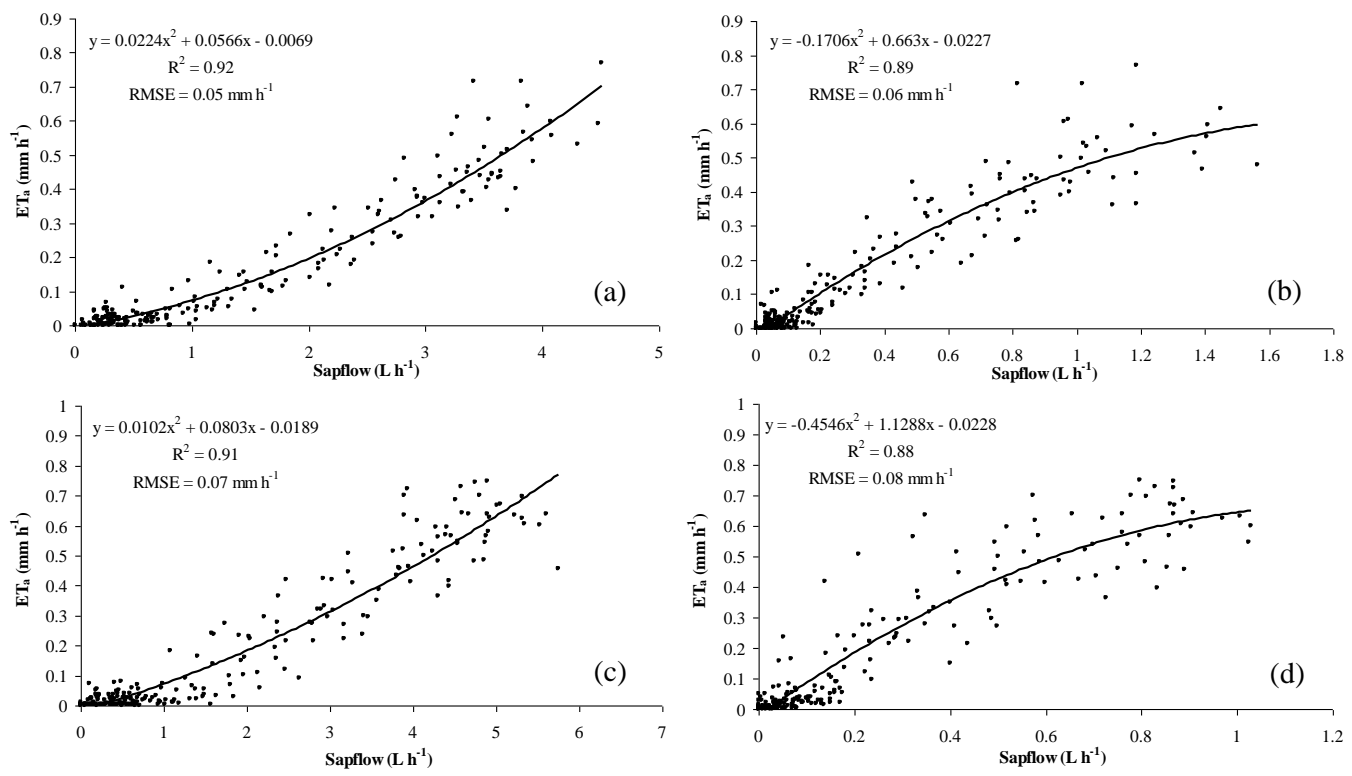

Figure 9. Polynomial regressions of actual total evaporation $\left(\mathrm{ET}_{\mathrm{a}}\right)$ against the hourly sap flow for the (a) emergent and (b) understory trees during November 2009, and the (c) emergent and (d) understory trees in March 2010.

and lower in November 2009 (1.1) and August 2009 (0.8). The $\alpha$, also estimated by the slope of the linear regression, was similar during the August (1.0) and November 2009 (1.0) field campaigns (Table 2) while during March 2010, $\alpha$ was slightly higher (1.1). The standard deviations and root mean square errors of $\alpha$ were higher than those of the $K_{\mathrm{c}}$ (Table 2). Therefore, the FAO Penman-Monteith $\mathrm{ET}_{\mathrm{o}}$ model was adopted as most suitable for use over the Nkazana PSF in this study.

The time interval (hourly and daily) at which the FAO Penman-Monteith $\mathrm{ET}_{\mathrm{O}}$ and Priestley-Taylor models were computed resulted in different $K_{\mathrm{c}}$ and $\alpha$ estimates. Daily computations used average daytime $T_{\text {air }}$, typically derived from an average of maximum and minimum daily $T_{\text {air }}$. In this research the models were run hourly and the average $T_{\text {air }}$ derived from $10 \mathrm{~s}$ measurements of $T_{\text {air }}$ (while $R_{\mathrm{n}}>0$ ) accurately representing that hour. However, using hourly data produced outliers in the calculation of $K_{\mathrm{c}}$ and $\alpha$ at the beginning or end of a day where the measured or modelled results are very small numbers, producing, from division, erroneous estimates of $K_{\mathrm{c}}$ and $\alpha$ (Eqs. 5 and 6). These typically occurred near sunset or sunrise and were filtered out of the data as they represented outliers. In addition, due to the vastly different canopy structures and heights within the Mfabeni Mire, of the SFW $(\sim 0.8 \mathrm{~m})$ and Nkazana PSF $(\sim 20$ $\mathrm{m})$, climatic data from above the forest was used as an input to the models to determine whether the SDs of $K_{\mathrm{c}}$ and $\alpha$ could be minimised, but no significant improvement was found. This indicated that the nearby weather station data (from within the SFW) was a suitable input for both models, supporting the application of these models using the standard
FAO Penman-Monteith $\mathrm{ET}_{\mathrm{o}}$ weather station sensor heights of $2 \mathrm{~m}$ (Allen et al., 2006).

\subsection{Modelling long-term actual total evaporation and monthly crop factors}

The long-term $\mathrm{ET}_{\mathrm{a}}$ (October 2009 to September 2010) was modelled through the relationship between the observed $\mathrm{ET}_{\mathrm{a}}$ and observed sap flow over the November 2009 and March 2010 field campaigns. In regressions of the emergent tree sap flow with $\mathrm{ET}_{\mathrm{a}}$ over the two field campaigns (Fig. 9a and c), it was found that there was little gain in using separate linear models for the two periods $\left(R^{2}=0.92\right.$ and 0.89 ; RMSE $=0.05 \mathrm{~mm} \mathrm{~h}^{-1}$ and $0.06 \mathrm{~mm} \mathrm{~h}^{-1}$ ) as a single, combined model described $\mathrm{ET}_{\mathrm{a}}$ equally well $\left(R^{2}=0.90\right.$; RMSE $=0.07 \mathrm{~mm} \mathrm{~h}^{-1}$ ). A similar result was found for the understory tree, indicating that for both trees a single relationship between $\mathrm{ET}_{\mathrm{a}}$ and sap flow represented both field campaigns.

In addition, a multiple regression, including the emergent and understory trees as predictors of $\mathrm{ET}_{\mathrm{a}}\left(R^{2}=0.91\right.$; RMSE $=0.08 \mathrm{~mm} \mathrm{~h}^{-1}$ ), provided insufficient benefit over the use of the single model based on only the emergent tree $\left(R^{2}=0.90 ; \mathrm{RMSE}=0.08 \mathrm{~mm} \mathrm{~h}^{-1}\right)$. The understory tree sap flow was considerably less (by $85 \%$ ) than that of the emergent tree and the density of the understory trees within the Nkazana PSF is much lower than the emergent trees. These results support the omission of the understory tree from the prediction of $\mathrm{ET}_{\mathrm{a}}$, and the use of the following model to estimate the $\mathrm{ET}_{\mathrm{a}}$ of the Nkazana PSF from hourly sap-flow data:

$$
\mathrm{ET}_{\mathrm{a}}=\left(0.16341 \cdot T_{\mathrm{r}}+0.06\right)^{2},
$$




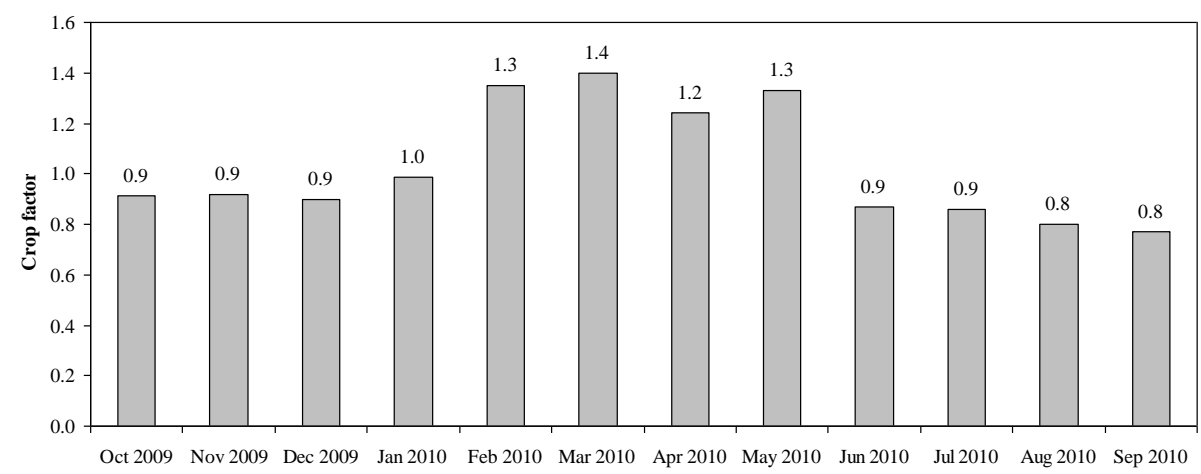

Figure 10. Monthly crop factors $K_{\mathrm{c}}$ for the Nkazana Peat Swamp Forest.

where $\mathrm{ET}_{\mathrm{a}}$ is the actual total evaporation $\left(\mathrm{mm} \mathrm{h}^{-1}\right)$ and $T_{\mathrm{r}}$ the emergent tree sap flow $\left(\mathrm{L} \mathrm{h}^{1}\right)$.

The annual $\mathrm{ET}_{\mathrm{a}}$ (October 2009 to September 2010) from the Nkazana PSF was $1125 \mathrm{~mm}$, over which period the rainfall was $650 \mathrm{~mm}$ (well below the long-term average, reported to be between 844 and $1200 \mathrm{~mm} \mathrm{a}^{-1}$ for the area). Finally, $K_{\mathrm{c}}$ was calculated at a daily interval from the extended $\mathrm{ET}_{\mathrm{a}}$ and $\mathrm{ET}_{\mathrm{o}}$ (Eq. 5), and averaged for each month of the year (Fig. 10). These results equated well with the results of $K_{\mathrm{c}}$ calculated during the field campaigns (Table 2) which were 0.8, 1.0 and 1.3 in August, November and March, respectively. During a distinct period from February to May, $K_{\mathrm{c}}$ was between 1.2 and 1.4 while for the rest of the year it was 0.8 to 1.0. When $K_{\mathrm{c}}=1$ the Nkazana PSF $\mathrm{ET}_{\mathrm{a}}$ equals the evaporative demand, or in other words $\mathrm{ET}_{\mathrm{o}}$. However, a $\mathrm{K}_{\mathrm{c}}$ of $<1$ or $>1$ indicates that the PSF ET $\mathrm{E}_{\mathrm{a}}$ is less than or greater than the $\mathrm{ET}_{\mathrm{o}}$, respectively. Figure 10 shows that the Nkazana $\mathrm{PSF} \mathrm{ET}_{\mathrm{a}}$ is at or just less than $\mathrm{ET}_{\mathrm{o}}$ for 8 months of the year (June to January) and greater than $\mathrm{ET}_{\mathrm{o}}$ for 4 months of the year (February to May).

The derived crop factors were verified using independent measurements of $\mathrm{ET}_{\mathrm{a}}$ over the Nkazana PSF collected during window periods at the same site from 8 to 12 August 2008 and 12 to 20 November 2008 in an experimental unpublished study conducted by the CSIR. The surface conditions during 2008 within the Nkazana PSF were much wetter as the water table was close to the surface with open water in low-lying areas whereas in 2009 and 2010 the dry period had caused the water level to drop resulting in only a few areas of open water within the forest. Despite this difference in groundwater level, the $K_{\mathrm{c}}$ was 0.8 in August of 2008 and 0.9 during November 2008, validating the results derived for $K_{\mathrm{c}}$ (from the extended record of $\mathrm{ET}_{\mathrm{a}}$ modelled from sap flow of the emergent tree), thus confirming that the $K_{\mathrm{c}}$ derived was applicable across wetter and drier years.

\subsection{Response of sap flow to climatic variables}

Equation (8) enabled the derivation of $\mathrm{ET}_{\mathrm{a}}$ over the period during which there were sap-flow measurements (October
2009 to September 2010). The purpose for this was to better understand the relationship between important climatic variables and $\mathrm{ET}_{\mathrm{a}}$. Three statistical approaches were used to determine these relationships with sap flow, which were directly related to $\mathrm{ET}_{\mathrm{a}}$ and the climatic variables. The simple linear regressions of daily sap flow were considered with radiant flux density and VPD and it was found that these were poor, with coefficients of determination of only 0.51 and 0.52 respectively (not shown). Clearly the relationship between climatic conditions and sap flow is more complex. By applying multiple regression analysis $I_{\mathrm{s}}, \mathrm{RH}, T_{\text {air }}$ and $\theta$ at $0.075 \mathrm{~m}$ were found to be significant $(p<0.001)$ with up to four-way interactions. Finally, a regression tree analysis was applied of hourly log-transformed sap flow with the meteorological variables $I_{\mathrm{s}}, \mathrm{RH}, T_{\text {air }}$ and $\theta$ (Fig. 11). This showed again that the relationships are complex but that $\mathrm{T}_{\text {air }}$ and $\theta$ were not required for the optimal split for the Nkazana PSF emergent tree sap flow. The most important split was between data with $I_{\mathrm{S}}$ of less than $55.7 \mathrm{~W} \mathrm{~m}^{-2}$ and data with $I_{\mathrm{S}}$ greater than $55.7 \mathrm{~W} \mathrm{~m}^{-2}$. Solar irradiance was clearly a key variable to include and the first split observed, essentially separates dayand night-time data. Solar irradiance was also highly correlated with $T_{\text {air }}$, which may be the reason $T_{\text {air }}$ was not found to be an additionally required variable. The next important splits were for RH above and below $93.2 \%$ for the nighttime data (essentially when it is raining and when it is not) and an additional split for $I_{\mathrm{S}}$ above and below $279.2 \mathrm{~W} \mathrm{~m}^{-2}$ for the daytime data; therefore splitting daytime data during high and low irradiance periods. At night the logged sap flow was found to be negative, with the greatest negative average logged sap flow when the RH was less than $96.4 \%$. The greatest average positive logged sap flow was found to be when $I_{\mathrm{S}}$ was greater than $279.2 \mathrm{~W} \mathrm{~m}^{-2}$, and this occurred $28 \%$ of the time.

\section{Discussion}

The EC method is recognised internationally to be a suitable and accurate technique for estimating $\mathrm{ET}_{\mathrm{a}}$ over vegetated 


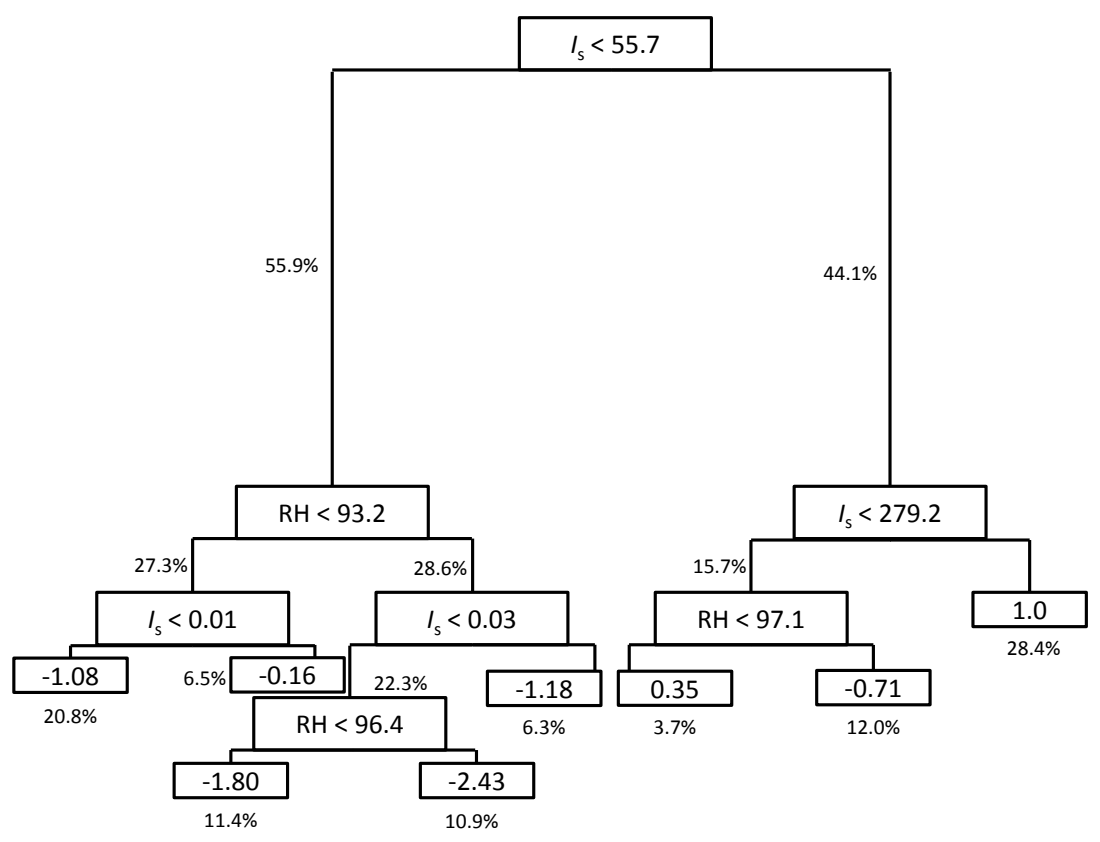

Figure 11. A regression tree analysis for sap flow showing the optimal splits of solar irradiance $\left(\mathrm{W} \mathrm{m}^{-2}\right)$ and relative humidity $(\%)$. Air temperature and volumetric water content were included, but these variables were not required for the optimal splits. The percentage of the total data at each split is also shown.

surfaces, and long-term EC measurements over the Nkazana PSF could provide the data required to understand the annual cycles of $\mathrm{ET}_{\mathrm{a}}$. However, EC systems have relatively high power requirements and need careful and frequent attendance as well as data checking, correction and analysis for complete records. The remote location of the Nkazana PSF, with no road access and difficult access on foot, high wind speeds and dangerous wild animals such as buffalo, rhinoceros, hippopotamus and crocodiles, prompted a research strategy to characterise the $\mathrm{ET}_{\mathrm{a}}$ of the Nkazana PSF during field campaigns conducted in representative seasons, as it was impractical to maintain a full EC system over an extended period of time (such as a year). There was a risk that a period of unusual weather could have coincided with the window periods (between 7 and 9 consecutive days at a time). However, the weather conditions during the field campaigns showed that a range of climatic conditions were captured that were representative of the seasons (Table 1). With this approach, field campaigns could be extended should unusual weather conditions be encountered over the planned measurement period.

The challenge remained in interpolating and extrapolating the $\mathrm{ET}_{\mathrm{a}}$ results from the $\mathrm{EC}$ system to annual $\mathrm{ET}_{\mathrm{a}}$. In longterm evaporation studies where gaps occur or where window periods have been used, and interpolation of the $\mathrm{ET}_{\mathrm{a}}$ record is required, meteorological models are typically used. Total evaporation has been estimated using models that are computationally simple such as the Priestley-Taylor model (Priestley and Taylor, 1972; Shuttleworth and Calder, 1979) to more complex models using multi-layer approaches within the canopy, but still based on the Penman-Monteith approach (Roberts et al., 1993; Harding et al., 1992), with significant deviations between measurements and modelled results. These meteorological models are, however, uncoupled from the transpiring vegetation and therefore the pattern of actual tree sap flow was considered in this study as a predictor of $\mathrm{ET}_{\mathrm{a}}$.

External regulation of sap flow has been described by numerous variables including the readily available soil water of the rooting area (Oren and Pataki, 2001), the micrometeorological conditions of the atmosphere (Lundblad and Lindroth, 2002), leaf area (Granier et al., 2000), canopy conductance (Granier et al., 2000), aerodynamic resistance (Jacobs and De Bruin, 1992; Hall, 2002), shading of lower leaves (Cienciala et al., 2000) and wind stress (Kim et al., 2014). However, it has been found that trees can have several mechanisms of internal regulation related to species-specific morphology and physiology that is partially uncoupled from the external conditions (Zweifel et al., 2005). Nevertheless, in most trees with actively transpiring leaves and some readily available soil water, a diurnal pattern of sap-flow results from a combination of internal and external conditions, which determines how a tree contributes to the $\mathrm{ET}_{\mathrm{a}}$ of a forest stand.

With advances in sap-flow measurement techniques, longterm forest $\mathrm{ET}_{\mathrm{a}}$ has been estimated by up-scaling from tree transpiration to forest $\mathrm{ET}_{\mathrm{a}}$ using various techniques generally based on sapwood area (Čermák et al., 2004). However, the large majority of these studies, especially where tree transpiration has been up-scaled, have been conducted in uni- 
form forest stands (Oren et al., 1999; Wilson et al., 2001) and much of the work has taken place in temperate boreal stands (Lundblad and Lindroth, 2002; Launiainen et al., 2011) and their applicability to other climatic zones needs consideration. In addition, it has also been recognised that transpiration often varies amongst species (Oren and Pataki, 2001; Ewers et al., 2002; Bowden and Bauerle, 2008) and up-scaling to forest transpiration in species-rich indigenous forests is complex.

The results from this study showed that the hourly sap flow of a single emergent tree, selected as a dominant species, correlated well with the hourly $\mathrm{ET}_{\mathrm{a}}$ measured over two window periods. In species-rich forests, measuring the sap flow of the different vegetation types (including the ferns, vines, understory and emergent trees) would be challenging, and upscaling questionable, due to the variety of plant structures within the canopy and our lack of information on the plant physiologies. Therefore, the empirical relationship between the single tree and $\mathrm{ET}_{\mathrm{a}}$ provided an ideal opportunity to derive the annual $\mathrm{ET}_{\mathrm{a}}$ of a vegetation type for which there is no information of the water-use characteristics. This relationship indicated that the emergent canopy trees are the main contributors to $\mathrm{ET}_{\mathrm{a}}$. The other contributors to $\mathrm{ET}_{\mathrm{a}}$, including open water, peat, ferns, vines and understory trees were either (1) insignificant contributors due to the low irradiance and VPD below the emergent tree canopy (supported by the low measured sap-flow rate of the understory tree), or (2) follow similar diurnal trends in evaporation and sap flow as the emergent tree (also supported by the diurnal trend in the sapflow rate of the understory tree) and are therefore captured in the empirical model of the emergent tree.

Variation of the energy balance closure discrepancy $(D)$ occurred between field campaigns, despite replication of the same instrumentation at the same site and with the same data processing procedures. Only the placement of the soil heat flux sensors changed slightly within the vicinity of the site between field campaigns. However, the soil heat fluxes (as a percent of net irradiance) fluctuated from 1 to $11 \%$, likely due to the specific placement of the sensors within the Nkazana PSF in a predominantly shaded area in contrast to a sunlit location due to gaps in the canopy. During August 2009 when $D=1$ (i.e. perfect closure of the energy balance), the soil heat flux was approximately $5 \%$ of $R_{\mathrm{n}}$ and was likely to be the most representative result for $G$ for a forested area, so agreeing with Dye et al. (2008). In March, $G$ was $11 \%$ of $R_{\mathrm{n}}$ and may have contributed to the poorest result of $D=1.33$. Wilson et al. (2002) found that energy balance closure, especially over forests, is seldom achieved. However, in most cases the magnitude of the long-term turbulent fluxes is lower than the available energy (Twine et al., 2000; Oliphant et al., 2004), which was not the case in the Nkazana PSF study where $D$ increased with increasing ET $_{\mathrm{a}}$ from August 2009 through November 2009 to March 2010.

An important observation, made over the three field campaigns, was that the average $\mathrm{ET}_{\mathrm{a}}$ measured during March $2010\left(4.4 \mathrm{~mm} \mathrm{day}^{-1}\right)$ did not correspond to the period of highest $R_{\mathrm{n}}$ (November 2009), which is commonly accepted to be one of the main driving variables in the process of $\mathrm{ET}_{\mathrm{a}}$ (Albaugh et al., 2013). This may indicate a lag in the $\mathrm{ET}_{\mathrm{a}}$ of the Nkazana PSF in relation to the maximum $R_{\mathrm{n}}$, possibly explaining the poor relationships observed between tree sap flow and climatic variables (such as $R_{\mathrm{n}}$ ). This lag was also observed in the high $K_{\mathrm{c}}$ values from February to May, where the $\mathrm{ET}_{\mathrm{a}}$ of the PSF was higher relative to $\mathrm{ET}_{\mathrm{o}}$. Typically, $K_{\mathrm{c}}$ is higher while vegetation is more actively transpiring and is associated with higher $I_{\mathrm{S}}$ and water availability, which in the Nkazana PSF would coincide with the summer period (October to March). However, the period of higher $K_{\mathrm{c}}$ values in the Nkazana PSF occurred quite late (February to May) in the summer season (Fig. 10). Clulow et al. (2013) showed the Nkazana PSF sap flow to be relatively consistent between seasons but that $\mathrm{ET}_{\mathrm{o}}$ rapidly decreased from February to May $\left(4.2 \mathrm{~mm} \mathrm{day}^{-1}\right.$ to $\left.2.4 \mathrm{~mm} \mathrm{day}^{-1}\right)$. The high $K_{\mathrm{c}}$ is therefore likely a result of decreasing $\mathrm{ET}_{\mathrm{o}}$ measured at the meteorological station, while transpiration rates in the Nkazana PSF were maintained into the late autumn period. A number of reasons may be attributed to this including the microclimate of the Nkazana PSF. For example, the lower energy loss at night from the ground and within the canopy, due to the combined effect of high water vapour levels (a greenhouse gas) and reduced infrared emission as a result of canopy absorbance, reflectance and re-emission downwards, compared to areas outside the PSF with shorter canopies, resulted in higher minimum daily temperatures (Fig. 4). The area adjacent to the Nkazana PSF where the automatic weather station was located (with a shorter canopy of approximately $1 \mathrm{~m}$ in height) experienced lower daily minimum temperatures (Fig. 4). The importance of this result is that $T_{\text {air }}$ affects biochemical processes such as photosynthesis and senescence. This $T_{\text {air }}$ difference, although greatest in winter, starts to build in January and could play a role in influencing the $\mathrm{ET}_{\mathrm{a}}$ in relation to the summer season as well as the period of higher $K_{\mathrm{c}}$ values in the latter half of summer.

Two important points regarding the weather station data and model calculations were noted. Firstly, where possible, hourly model time intervals should be used, which concurs with Irmak et al. (2005). However, this frequently resulted in outliers in $K_{\mathrm{c}}$ and $\alpha$ at the beginning or end of a day where the measured or modelled results were small numbers, producing, through division, erroneous estimates. It was therefore favourable to sum the hourly $\mathrm{ET}_{\mathrm{o}}$ and $\mathrm{ET}_{\mathrm{a}}$ data for each day (while $R_{\mathrm{n}}>0$ ) and calculate the daily $K_{\mathrm{c}}$ (which was then averaged for each month). Secondly, when calculating the $K_{\mathrm{c}}$ and $\alpha$ coefficients, there was no benefit in using the climatic data from above the tree canopy rather than the climatic data from the adjacent SFW of the Mfabeni Mire, which sufficiently represented the microclimate for the model calculations. This showed that data from nearby weather stations can be used with the $K_{\mathrm{c}}$ to estimate the $\mathrm{ET}_{\mathrm{a}}$ although this may only hold in humid environments where 
there is little difference in the VPD of the boundary layer conditions over the Nkazana PSF and the surrounding wetland areas, which are likely to all be at, or near, equilibrium evaporation.

The shape of the regressions of hourly $\mathrm{ET}_{\mathrm{a}}$ versus hourly sap flow (Fig. 9) during the window periods showed that sap flow of the emergent tree responded rapidly for low conditions of $\mathrm{ET}_{\mathrm{a}}$. These conditions occurred most frequently in the early morning and late afternoon when the angle of the $I_{\mathrm{S}}$ was low but still incident upon the emergent tree leaves. At higher rates of $\mathrm{ET}_{\mathrm{a}}$ the sap flow peaked as the physiology of the tree limited the sap-flow rates. In contrast, the understory tree sap-flow rate increased slowly relative to $\mathrm{ET}_{\mathrm{a}}$, while $\mathrm{ET}_{\mathrm{a}}$ was low, and exponentially for higher values of $\mathrm{ET}_{\mathrm{a}}$. This is likely due to shading of the understory trees for low sun angles (early morning and late afternoon) with $\mathrm{I}_{\mathrm{S}}$ limiting transpiration (together with the low VPD discussed above) with maximum rates occurring when shading by the emergent trees was at a minimum (noon) and $\mathrm{ET}_{\mathrm{a}}$ was at a maximum. These different responses of the trees indicated that a model to derive $\mathrm{ET}_{\mathrm{a}}$ from sap flow would require the inclusion of both emergent and understory trees. However, the sap flow and density of the understory trees was much lower than the emergent trees and therefore its inclusion in the empirical model was not found to significantly improve the relationship between entire canopy $\mathrm{ET}_{\mathrm{a}}$ and sap flow. This conclusion applies specifically to the Nkazana PSF. Some models such as the WAVES model permits two canopy simulations due to the importance of the understory canopy in some forest sites (Dye et al., 2008).

Within South Africa, the study by Dye et al. (2008) measured daily $\mathrm{ET}_{\mathrm{a}}$ of between 2 and $6 \mathrm{~mm}$ on clear days over three field campaigns during February, June and October 2004, which are comparable with the results from the Nkazana PSF of between $2.2 \mathrm{~mm}$ (August 2009) and $5.1 \mathrm{~mm}$ (March 2010). Internationally, no results of $\mathrm{ET}_{\mathrm{a}}$ or modelling guidelines for peat swamp forests were found, signifying the unique contribution of this study.

The comparison of meteorological variables with sap flow revealed that it is unlikely that a single climatic variable is able to determine sap flow, and in turn $\mathrm{ET}_{\mathrm{a}}$. The relationships were revealed to be non-linear, and thus to model sap flow accurately, data need to be subset into different periods - at least into day and night.

\section{Conclusions and opportunities for further research}

This study has portrayed the difficulties of using the most advanced systems available to measure $\mathrm{ET}_{\mathrm{a}}$, such as $\mathrm{EC}$, in remote and difficult-to-access areas. It has shown that intensive window period measurements using high-maintenance EC systems provide reliable and continuous measurements of $\mathrm{ET}_{\mathrm{a}}$ but require a method to determine the $\mathrm{ET}_{\mathrm{a}}$ during the in-between periods to be able to estimate long-term $\mathrm{ET}_{\mathrm{a}}$.
This was overcome by measuring the long-term sap flow of an emergent canopy tree and deriving a qualitative model for $\mathrm{ET}_{\mathrm{a}}$ based on sap-flow measurements. Further research on the benefit of measuring multiple emergent trees and the possible variability of transpiration within different species and the extent to which this could improve the long-term estimate of forest $\mathrm{ET}_{\mathrm{a}}$ together with window periods of $\mathrm{EC}$ data would be beneficial.

Energy balance closure discrepancy $(D)$ remains an unresolved matter which affects flux measurements such as $\mathrm{ET}_{\mathrm{a}}$ and $\mathrm{CO}_{2}$. Corrections suggested in research studies can be applied but without conclusively identifying the source of the error in the observations. In contrast to most studies reported, the closure discrepancy of the energy balance over the Nkazana PSF was greater than 1 for two of the field campaigns. Although attributed in part to unrepresentative $G$ measurements, $D$ increased as $\mathrm{ET}_{\mathrm{a}}$ increased.

The model used to derive the annual $\mathrm{ET}_{\mathrm{a}}$ from sap flow (Eq. 8), and then monthly crop factors, was verified with data from two independent field campaigns in 2008, when conditions were much wetter and there were larger areas of open water within the forest. The much wetter conditions in 2008 did not alter the $K_{\mathrm{c}}$ thus indicating that the relationship between $\mathrm{ET}_{\mathrm{a}}$ and $\mathrm{ET}_{\mathrm{o}}$ remained constant and that the $K_{\mathrm{c}}$ derived can be applied over a range of climatic conditions. In addition, it indicates that the humid, low-VPD environment within the forest canopy minimises the contribution of open water evaporation within the forest to $\mathrm{ET}_{\mathrm{a}}$. However, the general dearth of information on the $\mathrm{ET}_{\mathrm{a}}$ of subtropical indigenous forests internationally allows little comparison of the results obtained from the Nkazana PSF and similar forest types and knowledge of the extent to which these crop factors can be extrapolated geographically and to similar forests would benefit from further comparisons.

The Mfabeni Mire is actively managed by the iSimangaliso Wetland Park. These results provide the basis for improved estimates of the $\mathrm{ET}_{\mathrm{a}}$ component of the Nkazana PSF water balance and the environmental water requirements. Water is critical to the functioning of this ecosystem for biotic and abiotic life, the sequestration or release of carbon from the Mire and also to the spread of fires. The annual $\mathrm{ET}_{\mathrm{a}}$ estimated in this study $(1125 \mathrm{~mm})$ was even higher than the range (844 to $1200 \mathrm{~mm} \mathrm{yr}^{-1}$ ) of reported estimates of mean annual precipitation for the area (Lynch, 2004; Taylor et al., 2006; ARC-ISCW, 2011).

The difference between $\mathrm{ET}_{\mathrm{a}}$ and rainfall highlights the importance of the groundwater contributions and the critical role it plays in assuring the survival of this groundwaterdependant ecosystem. The groundwater available to the Mfabeni Mire is in part determined by the management of the upstream catchments and the groundwater levels of the greater Zululand Coastal Aquifer, emphasising the need for an integrated catchment management approach to the area. 
Acknowledgements. This research was funded by Key Strategic Area 2 (i.e. Water-Linked Ecosystems) of the Water Research Commission (WRC) of South Africa and the Council for Scientific and Industrial Research and forms part of an unsolicited research project (Evapotranspiration from the Nkazana Swamp Forest and Mfabeni Mire). The iSimangaliso Wetland Park are acknowledged for their support in providing access to the research sites. Craig Morris provided invaluable statistical analysis and support. Assistance in the field by Piet-Louis Grundling, Siphiwe Mfeka, Scott Ketcheson, David Clulow, Lelethu Sinuka and the late Joshua Xaba is much appreciated.

Edited by: A. van Griensven

\section{References}

Albaugh, J. M., Dye, P. J., and King, J. S.: Eucalyptus and Water Use in South Africa, Int. J. For. Res., 11, 852540, doi:10.1155/2013/852540, 2013.

Allen, R., Walter, I., Elliott, R., Mecham, B., Jensen, M., Itenfisu, D., Howell, T., Snyder, R., Brown, P., and Echings, S.: Issues, requirements and challenges in selecting and specifying a standardized ET equation, Proc., 4th National Irrigation Symp, 201208, 2000

Allen, R. G., Pereira, L. S., Raes, D., and Smith, M.: Crop evapotranspiration: Guidelines for computing crop water requirements, FAO Irrigation and Drainage Paper 56, Food and Agriculture Organization of the United Nations, Rome, Italy, 1998.

Allen, R. G., Pruitt, W. O., Wright, J. L., Howell, T. A., Ventura, F., Snyder, R., Itenfisu, D., Steduto, P., Berengena, J., Yrisarry, J. B., Smith, M., Pereira, L. S., Raes, D., Perrier, A., Alves, I., Walter, I., and Elliott, R.: A recommendation on standardized surface resistance for hourly calculation of reference ETo by the FAO56 Penman-Monteith method, Agric. Water Manage., 81, 122, 2006.

Andrade, J. L. and Nobel, P. S.: Microhabitats and Water Relations of Epiphytic Cacti and Ferns in a Lowland Neotropical Forest1, Biotropica, 29, 261-270, 1997.

ARC-ISCW (Agricultural Research Council-Institute for Soil, Climate and Water): National AgroMet, Climate Databank, ARCISCW, Pretoria, South Africa, 2011.

Baldocchi, D. D., Hincks, B. B., and Meyers, T. P.: Measuring Biosphere-Atmosphere Exchanges of Biologically Related Gases with Micrometeorological Methods, Ecology, 69, 13311340, 1988.

Baldocchi, D., Valentini, R., Running, S., Oechel, W., and Dahlman, R.: Strategies for measuring and modelling carbon dioxide and water vapour fluxes over terrestrial ecosystems, Global Change Biol., 2, 159-168, 1996.

Baldocchi, D., Falge, E., Gu, L., Olson, R., Hollinger, D., Running, S., Anthoni, P., Bernhofer, C., Davis, K., Evans, R., Fuentes, J., Goldstein, A., Katul, G., Law, B., Lee, X., Malhi, Y., Meyers, T., Munger, W., Oechel, W., Paw, K. T., Pilegaard, K., Schmid, H. P., Valentini, R., Verma, S., Vesala, T., Wilson, K., and Wofsy, S.: FLUXNET: A New Tool to Study the Temporal and Spatial Variability of Ecosystem-Scale Carbon Dioxide, Water Vapor, and Energy Flux Densities, B. Am. Meteorol. Soc., 82, 24152434, 2001.
Barr, A. G., Morgenstern, K., Black, T. A., McCaughey, J. H., and Nesic, Z.: Surface energy balance closure by the eddy-covariance method above three boreal forest stands and implications for the measurement of the $\mathrm{CO}_{2}$ flux, Agr. For. Meteorol., 140, 322-337, 2006.

Bowen, I. S.: The ratio of heat losses by conduction and by evaporation from any water surface, Phys. Rev., 27, 779-787, 1926.

Bowden, J. D. and Bauerle, W. L.: Measuring and modeling the variation in species-specific transpiration in temperate deciduous hardwoods, Tree Physiol., 28, 1675-1683, 2008.

Burgess, S. S. O., Adams, M. A., Turner, N. C., Beverly, C. R., Ong, C. K., Khan, A. A. H., and Bleby, T. M.: An improved heat pulse method to measure low and reverse rates of sap flow in woody plants, Tree Physiol., 21, 589-598, 2001.

Cava, D., Contini, D., Donateo, A., and Martano, P.: Analysis of short-term closure of the surface energy balance above short vegetation, Agr. For. Meteorol., 148, 82-93, 2008.

Čermák, J., Kučera, J., and Nadezhdina, N.: Sap flow measurement with some thermodynamic methods, flow integration within trees and scaling up from sample trees to entire forest stands, Trees, 18, 529-546, 2004.

Čermák, J. and Nadezhdina, N.: Sapwood as the scaling parameterdefining according to xylem water content or radial pattern of sap flow?, Ann. For. Sci., 55, 509-521, 1998.

Cienciala, E., Kučera, J., and Malmer, A.: Tree sap flow and stand transpiration of two Acacia mangium plantations in Sabah, Borneo, Journal of Hydrology, 236, 109-120, 2000.

Clulow, A. D., Everson, C. S., Mengistu, M. G., Jarmain, C., Jewitt, G. P. W., Price, J. S., and Grundling, P.-L.: Measurement and modelling of evaporation from a coastal wetland in Maputaland, South Africa, Hydrol. Earth Syst. Sci., 16, 3233-3247, doi:10.5194/hess-16-3233-2012, 2012.

Clulow, A. D., Everson, C. S., Price, J. S., Jewitt, G. P. W., and Scott-Shaw, B. C.: Water-use dynamics of a peat swamp forest and a dune forest in Maputaland, South Africa, Hydrol. Earth Syst. Sci., 17, 2053-2067, doi:10.5194/hess-17-20532013, 2013.

Crosbie, R., Wilson, B., Hughes, J., and McCulloch, C.: The upscaling of transpiration from individual trees to areal transpiration in tree belts, Plant Soil, 297, 223-232, 2007.

Davies, J. A., and Allen, C. D.: Equilibrium, Potential and Actual Evaporation from Cropped Surfaces in Southern Ontario, J. Appl. Meteorol., 12, 649-657, 1973.

Drexler, J. Z., Snyder, R. L., Spano, D., and Paw U. K. T.: A review of models and micrometeorological methods used to estimate wetland evapotranspiration, Hydrol. Process., 18, 20712101, 2004.

Duursma, R. A. and Medlyn, B. E.: MAESPA: a model to study interactions between water limitation, environmental drivers and vegetation function at tree and stand levels, with an example application to $\left[\mathrm{CO}_{2}\right] \times$ drought interactions, Geosci. Model Dev., 5, 919-940, doi:10.5194/gmd-5-919-2012, 2012.

Dye, P. J., Gush, M. B., Everson, C. S., Jarmain, C., Clulow, A., Mengistu, M., Geldenhuys, C. J., Wise, R., Scholes, R. J., Archibald, S., and Savage, M. J.: Water-use in relation to biomass of indigenous tree species in woodland, forest and/or plantation conditions, Water Research Commission Report No. 361/08, ISBN 978-1-77005-744-9, Pretoria, South Africa, 156 pp., 2008. 
Ewers, B. E., Mackay, D. S., Gower, S. T., Ahl, D. E., Burrows, S. N., and Samanta, S. S.: Tree species effects on stand transpiration in northern Wisconsin, Water Resour. Res., 38, 8-1-8-11, 2002. Falge, E., Baldocchi, D., Olson, R., Anthoni, P., Aubinet, M., Bernhofer, C., Burba, G., Ceulemans, R., Clement, R., Dolman, H., Granier, A., Gross, P., Grünwald, T., Hollinger, D., Jensen, N.-O., Katul, G., Keronen, P., Kowalski, A., Lai, C. T., Law, B. E., Meyers, T., Moncrieff, J., Moors, E., Munger, J. W., Pilegaard, K., Rannik, Ü., Rebmann, C., Suyker, A., Tenhunen, J., Tu, K., Verma, S., Vesala, T., Wilson, K., and Wofsy, S.: Gap filling strategies for defensible annual sums of net ecosystem exchange, Agr. For. Meteorol., 107, 43-69, 2001.

Finch, J. W.: A comparison between measured and modelled open water evaporation from a reservoir in south-east England, Hydrol. Proc., 15, 2771-2778, 2001.

Finnigan, J. J., Clement, R., Malhi, Y., Leuning, R., and Cleugh, H. A.: A Re-Evaluation of Long-Term Flux Measurement Techniques Part I: Averaging and Coordinate Rotation, Bound.-Layer Meteorol., 107, 1-48, 2003.

Flint, A. L. and Childs, S. W.: Use of the Priestley-Taylor evaporation equation for soil water limited conditions in a small forest clearcut, Agr. For. Meteorol., 56, 247-260, 1991.

Granier, A., Loustau, D., and Bréda, N.: A generic model of forest canopy conductance dependent on climate, soil water availability and leaf area index, Ann. For. Sci., 57, 755-765, 2000.

Grelle, A. and Lindroth, A.: Eddy-correlation system for long-term monitoring of fluxes of heat, water vapour and $\mathrm{CO}_{2}$, Global Change Biol., 2, 297-307, 1996.

Grundling, A. T., van den Berg, E. C., and Pretorius, M. L.: Influence of regional environmental factors on the distribution, characteristics and functioning of hydrogeomorphic wetland types on the Maputaland Coastal Plain, KwaZulu-Natal, South Africa, Water Research Commission Report No. 1923/1/13, ISBN 9781-4312-0492-2, Pretoria, South Africa, 156 pp., 2014.

Grundling, P.-L., Mazus, H., and Baartman, L.: Peat resources in northern KwaZulu-Natal wetlands: Maputaland, Department of Environmental Affairs and Tourism Pretoria, South Africa, 102 pp., 1998.

Hall, R. L.: Aerodynamic resistance of coppiced poplar, Agr. For. Meteorol., 114, 83-102, 2002.

Harding, R. J., Hall, R. L., Neal, C., Roberts, J. M., Rosier, P. T. W., and Kinniburgh, D. G.: Hydrological impacts of broad leaf wood lands: implications for water use and water quality. Project report 115/03/ST, National Rivers Authority, Bristol, 135 pp., 1992.

Hatton, T. J. and Wu, H.-I.: Scaling theory to extrapolate individual tree water use to stand water use, Hydrol. Proc., 9, 527-540, 1995.

Hui, D., Wan, S., Su, B., Katul, G., Monson, R., and Luo, Y.: Gapfilling missing data in eddy covariance measurements using multiple imputation (MI) for annual estimations, Agr. For. Meteorol., 121, 93-111, 2004.

Irmak, S., Howell, T. A. , Allen, R. G. , Payero, J. O., and Martin, D. L.: Standardized ASCE-Penman-Monteith: Impact of sumof-hourly vs. 24-hr-timestep computations at Reference Weather Station Sites, Trans. ASABE, 48, 1063-1077, 2005.

Jacobs, C. M. J. and De Bruin, H. A. R.: The sensitivity of regional transpiration to land-surface characteristics: significance of feedback, J. Climate, 5, 683-698, 1992.
Kim, D., Oren, R., Oishi, A. C., Hsieh, C.-I., Phillips, N., Novick, K. A., and Stoy, P. C.: Sensitivity of stand transpiration to wind velocity in a mixed broadleaved deciduous forest, Agr. For. Meteorol., 187, 62-71, 2014.

Koerselman, W. and Beltman, B.: Evapotranspiration from fens in relation to Penman's potential free water evaporation (EO) and pan evaporation, Aquat. Bot., 31, 307-320, 1988.

Lafleur, P. M. and Roulet, N. T.: A comparison of evaporation rates from two fens of the Hudson Bay Lowland, Aquat. Bot., 44, 5969, 1992.

Launiainen, S., Katul, G. G., Kolari, P., Vesala, T., and Hari, P.: Empirical and optimal stomatal controls on leaf and ecosystem level $\mathrm{CO}_{2}$ and $\mathrm{H}_{2} \mathrm{O}$ exchange rates, Agr. For. Meteorol., 151, 1672-1689, 2011.

Lundblad, M. and Lindroth, A.: Stand transpiration and sapflow density in relation to weather, soil moisture and stand characteristics, Basic Appl. Ecol., 3, 229-243, 2002.

Lynch, S. D.: Development of a raster database of annual, monthly and daily rainfall for Southern Africa, Report to the Water Research Commission, ISBN Number: 1-77005-250-X, Water Research Commission, Pretoria, South Africa, 2004.

Mao, L. M., Bergman, M. J., and Tai, C. C.: Evapotranspiration measurement and estimation of three wetland environments in the upper St. Johns River Basin, Florida, J. Am. Water Res. Ass., 38, 1271-1285, 2002.

Massman, W. J. and Lee, X.: Eddy covariance flux corrections and uncertainties in long-term studies of carbon and energy exchanges, Agr. For. Meteorol., 113, 121-144, 2002.

Meiresonne, L., Nadezhdin, N., Čermák, J., Van Slycken, J., and Ceulemans, R.: Measured sap flow and simulated transpiration from a poplar stand in Flanders (Belgium), Agr. For. Meteorol., 96, 165-179, 1999.

Meyers, T. P. and Baldocchi, D. D.: Current Micrometeorological Flux Methodologies with Applications in Agriculture, in: Micrometeorology in Agricultural Systems, edited by: Hatfield, J. L., and Baker, J. M., Agronomy Monograph no. 47, American Society of Agronomy, Crop Science Society of America, and Soil Science Society of America, 381-396, 2005.

Monteith, J. L.: Evaporation and environment: the state and movement of water in living organisms, Symp. Soc. Exp. Biol., 19, 205-234, 1965.

Mucina, L. and Rutherford, M. C. (Eds.): The Vegetation of South Africa, Lesotho and Swaziland, Strelitzia 19, South African National Biodiversity Institute, Pretoria, South Africa, 2006.

Nichols, D. S. and Brown, J. M.: Evaporation from a sphagnum moss surface, J. Hydrol., 48, 289-302, 1980.

Oliphant, A. J., Grimmond, C. S. B., Zutter, H. N., Schmid, H. P., Su, H. B., Scott, S. L., Offerle, B., Randolph, J. C., and Ehman, J.: Heat storage and energy balance fluxes for a temperate deciduous forest, Agr. For. Meteorol., 126, 185-201, 2004.

Oncley, S., Foken, T., Vogt, R., Kohsiek, W., DeBruin, H. A. R., Bernhofer, C., Christen, A., Gorsel, E., Grantz, D., Feigenwinter, C., Lehner, I., Liebethal, C., Liu, H., Mauder, M., Pitacco, A., Ribeiro, L., and Weidinger, T.: The Energy Balance Experiment EBEX-2000. Part I: overview and energy balance, Bound.-Layer Meteorol., 123, 1-28, 2007.

Oren, R. and Pataki, D. E.: Transpiration in Response to Variation in Microclimate and Soil Moisture in Southeastern Deciduous Forests, Oecologia, 127, 549-559, 2001. 
Oren, R., Phillips, N., Ewers, B. E., Pataki, D. E., and Megonigal, J. P.: Sap-flux-scaled transpiration responses to light, vapor pressure deficit, and leaf area reduction in a flooded Taxodium distichum forest, Tree Physiol., 19, 337-347, 1999.

Penman, H. L.: Natural Evaporation from Open Water, Bare Soil and Grass, Proc. Roy. Soc. Ldn. A Math. Phys. Sci., 193, 120 $145,1948$.

Price, J. S.: Blanket bog in Newfoundland: Part 2. Hydrological processes, J. Hydrol., 135, 103-119, 1992.

Priestley, C. H. B. and Taylor, R. J.: On the Assessment of Surface Heat Flux and Evaporation Using Large-Scale Parameters, Mon. Weather Rev., 100, 81-92, 1972.

Roberts, J., Cabral, O. M. R., Fisch, G., Molion, L. C. B., Moore, C. J., and Shuttleworth, W. J.: Transpiration from an Amazonian rainforest calculated from stomatal conductance measurements, Agr. For. Meteorol., 65, 175-196, 1993.

Rosenberry, D. O., Winter, T. C., Buso, D. C., and Likens, G. E.: Comparison of 15 evaporation methods applied to a small mountain lake in the northeastern USA, J. Hydrol., 340, 149-166, 2007

Savage, M. J., Everson, C. S., and Metelerkamp, B. R.: Evaporation measurement above vegetated surfaces using micrometeorological techniques, Water Research Commission Report No. 349/1/97, ISBN 1-86845 363 4, Water Research Commission, Pretoria, South Africa, 248 pp., 1997.

Savage, M. J., Everson, C. S., Odhiambo, G. O., Mengistu. M. G., and Jarmain. C.: Theory and practice of evaporation measurement, with a special focus on SLS as an operational tool for the estimation of spatially-averaged evaporation, Water Research Commission Report No. 1335/1/04, ISBN 1-77005-247-X, Pretoria, South Africa, 204 pp., 2004.

Schulze, R. E., Maharaj, M., Warburton, M. L., Gers, C. J., Horan, M. J. C., Kunz, R. P., and Clark, D. J.: South African Atlas of Climatology and Agrohydrology, Water Research Commission Report No. 1489/1/08, Water Research Commission, Pretoria, South Africa, 2008.

Shuttleworth, W. J. and Calder, I. R.: Has the Priestley-Taylor Equation Any Relevance to Forest Evaporation?, J. Appl. Meteorol., 18, 639-646, 1979.

Souch, C., Wolfe, C. P., and Grimmtind, C. S. B.: Wetland evaporation and energy partitioning: Indiana Dunes National Lakeshore, J. Hydrol., 184, 189-208, 1996.

Sumner, D. M. and Jacobs, J. M.: Utility of Penman-Monteith, Priestley-Taylor, reference evapotranspiration, and pan evaporation methods to estimate pasture evapotranspiration, J. Hydrol., 308, 81-104, 2005.

Tanner, C. B.: Energy balance approach to evapotranspiration from crops, Soil Sci. Soc. Am. Proc., 24, 1-9, 1960

Taylor, R.: The Greater St Lucia Wetland Park, Parke-Davis for Natal Parks Board, Pietermaritzburg, South Africa, 1991.

Taylor, R., Kelbe, B., Haldorsen, S., Botha, G. A., Wejden, B., Vaeret, L., and Simonsen, M. B.: Groundwater-dependent ecology of the shoreline of the subtropical Lake St Lucia estuary, Environ. Geol., 49, 586-600, 2006.

Thom, A. S.: Momentum, mass and heat exchange in plant communities, in: Vegetation and the Atmosphere, Vol. 1, Principals, edited by: Monteith, J. L., Acad. Press., London, 57-109, 1975.
Thompson, M. A., Campbell, D. I., and Spronken-Smith, R. A.: Evaporation from natural and modified raised peat bogs in New Zealand, Agr. For. Meteorol., 95, 85-98, 1999.

Traver, E., Ewers, B. E., Mackay, D. S., and Loranty, M. M.: Tree transpiration varies spatially in response to atmospheric but not edaphic conditions, Funct. Ecol., 24, 273-282, 2010.

Twine, T. E., Kustas, W. P., Norman, J. M., Cook, D. R., Houser, P. R., Meyers, T. P., Prueger, J. H., Starks, P. J., and Wesely, M. L.: Correcting eddy-covariance flux underestimates over a grassland, Agr. For. Meteorol., 103, 279-300, 2000.

Utset, A., Farré, I., Martínez-Cob, A., and Cavero, J.: Comparing Penman-Monteith and Priestley-Taylor approaches as referenceevapotranspiration inputs for modeling maize water-use under Mediterranean conditions, Agric. Water Manage., 66, 205-219, 2004.

Vaeret, L. and Sokolic, F.: Methods for studying the distribution of groundwater-dependent wetlands: a case study from Eastern Shores, St Lucia, South Africa, in: Responses to global change and management actions in coastal groundwater resources, edited by: Vaeret, L., Maputaland, southeast Africa, PhD Thesis, Norwegian University of Life Sciences, Norway, 2008.

Vandegehuchte, M. W. and Steppe, K.: Use of the correct heat conduction-convection equation as basis for heat-pulse sap flow methods in anisotropic wood, J. Exp. Bot., 63, 2833-2839, doi:10.1093/jxb/ers041, 2012.

Vertessy, R. A., Hatton, T. J., Reece, P., O’Sullivan, S. K., and Benyon, R. G.: Estimating stand water use of large mountain ash trees and validation of the sap flow measurement technique, Tree Physiol., 17, 747-756, 1997.

von Maltitz, G., Mucina, L., Geldenhuys, C. J., Lawes, M. J., Eeley, H., Aidie, H., Vink, D., Fleming, G., and Bailey, C.: Classification system for South African Indigenous Forests, An objective classification for the Department of Water Affairs and Forestry, Unpublished report, No. ENV-P-C 2003-017, Environmentek, CSIR, Pretoria, 275 pp., 2003.

Vourlitis, G. L., Filho, N. P., Hayashi, M. M. S., de S. Nogueira, J., Caseiro, F. T., and Campelo, J. H.: Seasonal variations in the evapotranspiration of a transitional tropical forest of Mato Grosso, Brazil, Water Resources Research, 38, 30-1-30-11, 2002.

Vrdoljak, S. M. and Hart, R. C.: Groundwater seeps as potentially important refugia for freshwater fishes on the Eastern Shores of Lake St Lucia, KwaZulu-Natal, South Africa, Afr. J. Aquat. Sci., 32, 125-132, 2007.

VSN International: GenStat for Windows 14th Edition, VSN International, Hemel Hempstead, UK, available at: http://GenStat.co. uk (last access: 24 January 2013), 2011.

Wessels, N. G.: Aspects of the ecology and conservation of swamp forests in South Africa, unpublished M. Tech thesis, Port Elizabeth Technikon, Port Elizabeth, South Africa, 155 pp., 1997.

Whitfield, A. K. and Taylor, R. H.: A review of the importance of freshwater inflow to the future conservation of Lake St Lucia, Aquat. Conserv. Mar. Freshwat. Ecosyst., 19, 838-848, 2009.

Wilson, K. B., Hanson, P. J., Mulholland, P. J., Baldocchi, D. D., and Wullschleger, S. D.: A comparison of methods for determining forest evapotranspiration and its components: sap-flow, soil water budget, eddy covariance and catchment water balance, Agr. For. Meteorol., 106, 153-168, 2001. 
Wilson, K., Goldstein, A., Falge, E., Aubinet, M., Baldocchi, D., Berbigier, P., Bernhofer, C., Ceulemans, R., Dolman, H., Field, C., Grelle, A., Ibrom, A., Law, B. E., Kowalski, A., Meyers, T., Moncrieff, J., Monson, R., Oechel, W., Tenhunen, J., Valentini, R., and Verma, S.: Energy balance closure at FLUXNET sites, Agr. For. Meteorol., 113, 223-243, 2002.

WMO: Guide to Meteorological Instruments and Methods of Observation, WMO-No.8, 7th Edn., Geneva, 2008.
Wullschleger, S. D., Hanson, P. J., and Todd, D. E.: Transpiration from a multi-species deciduous forest as estimated by xylem sap flow techniques, For. Ecol. Manage., 143, 205-213, 2001.

Zweifel, R., Zimmermann, L., and Newbery, D. M.: Modeling tree water deficit from microclimate: an approach to quantifying drought stress, Tree Physiol., 25, 147-156, 2005. 